\title{
PALAEOENVIRONMENT AND SHORELINE DISPLACEMENT ON SUURSAARI ISLAND, THE GULF OF FINLAND
}

\author{
ATKO HEINSALU, SIIM VESKI and JÜRI VASSILJEV
}

HEINSALU, ATKO, VESKI, SIIM and VASSILJEV, JÜRI 2000. Palaeoenvironment and shoreline displacement on Suursaari Island, the Gulf of Finland. Bulletin of the Geological Society of Finland 72, Parts 1-2, 21-46.

The island of Suursaari in the middle of the Gulf of Finland is exceptionally high (175 $\mathrm{m}$ a.s.1.). Sediment profiles from one mire and three lakes were investigated using diatom and pollen analysis, radiocarbon dating and levelling of the elevations of ancient shorelines. The pollen stratigraphy of the Lounatkorkiasuo Mire sediment suggests a sedimentary record dating from the late Allerød. The development of late-glacial vegetation went through the same phases as in southern Finland, however these are probably somewhat earlier on the island of Suursaari. There are differences in the Holocene vegetation history of the higher and lower areas of the island. Lake Ruokalahenjärvi was isolated around $10000 \mathrm{BP}$ during the initial phase of the Yoldia Sea and the diatom assemblage indicates that at that time brackish-water flow had not penetrated into the Gulf of Finland. Diatoms from the isolation sediments of Lake Liivalahenjärvi and Lake Veteljärvi indicate a freshwater environment for the Yoldia Sea final phase at 9500-9600 BP. Levelling of coastal formations on Suursaari Island reveals that the Late Weichselian and early Holocene ancient shorelines are 5-15 m higher than expected from the isobase data for similar land uplift areas on the mainland. The anomalous shoreline levels on Suursaari Island may be explained by irregular land uplift. By the time of the Litorina Sea differences in shoreline altitudes had disappeared.

Key words: paleoenvironment, sea-level changes, mires, lake sediments, pollen analysis, diatoms, paleobotany, raised beaches, Baltic Sea Stages, Quaternary, Baltic Sea, Suursaari, Russian Federation

Atko Heinsalu: Institute of Geology at Tallinn Technical University, Estonia pst. 7, 10143 Tallinn, Estonia, and Department of Quaternary Geology, University of Turku, FIN-20014, Finland.

E-mail: heinsalu@gi.ee

Siim Veski and Jüri Vassiljev: Institute of Geology at Tallinn Technical University, Estonia pst. 7, 10143 Tallinn, Estonia.

E-mails:veski@gi.ee andvassilje@gi.ee 


\section{INTRODUCTION}

Palaeoenvironmental studies and reconstruction of the history of the Baltic Sea have a long tradition in both Finland and Estonia. Several attempts have been made to correlate the various stages of the Baltic Sea on both sides of the Gulf of Finland, namely comparing the ages of transgressions and regressions, different shore displacement curves, and litho- and biostratigraphy (e.g. Sauramo 1958, Donner 1966, Kessel et al. 1988, Raukas \& Hyvärinen 1992). There is, however, a lack of biostratigraphic studies of offshore sediments in the Gulf of Finland (Åker et al. 1988) so that a gap in the geological record between Estonia and Finland remains and hinders correlation and reconstruction of the history of the Baltic Sea.

The island of Suursaari (Hogland) is located in the middle of the Gulf of Finland, about halfway between Estonia and Finland. It has unusually high relief $(175 \mathrm{~m})$ and possesses numerous sets of shore deposits and features at various altitudes. Surveying the altitude of ancient beach-ridges, measurement of the thresholds of lakes and mires, and sediment coring and sampling of three lakes and one mire were carried out during short visits to Suursaari Island by a group of Estonian geologists in the summers of 1989 and 1990. The basal part of the four sediment cores were investigated by means of diatom and pollen analysis and were radiocarbon dated (Table 1). These records offer excellent material for palaeoenvironmental reconstruction of the area following the final deglaciation of the Gulf of Finland. Moreover, the data allow correlation of the shore displacement patterns of the Baltic Sea between Estonia and Finland.

\section{STUDY AREA}

The island of Suursaari (Hogland) is located in the Gulf of Finland $\left(60^{\circ} \mathrm{N}, 27^{\circ} \mathrm{E}\right), 40 \mathrm{~km}$ south of the coast of Finland and $55 \mathrm{~km}$ north of the Estonian mainland (Fig. 1). The island was previously part of Finland but was surrendered to the Soviet Union in 1944 and has since been oc- cupied by military troops. For that reason access to the island has been very limited for the last fifty years.

The length of the NNW-SSE elongated island is $11 \mathrm{~km}$ and its largest width is $3 \mathrm{~km}$. The highest points on the island are, in the north, Pohjoiskorkia (108 $\mathrm{m}$ a.s.1.), in the middle, Haukkavuori (142 $\mathrm{m}$ a.s.1.) and, in the south, the summit, Lounatkorkia (175 $\mathrm{m}$ a.s.1.). This relief is exceptional among the islands of the Gulf of Finland.

The bedrock of the island is crystalline and consists mostly of Precambrian Svecofennian gneisses, gabbros and granites in the western part of the island and of Subjotnian quartz porphyries and quartzite conglomerates in the east (Puura et al. 1992). Quaternary sediments are mainly limited to valleys, the dominant type being coarse shoreline deposits occurring as boulder ridges, boulder or shingle fields, or shoreline scarps, at various altitudes throughout the island. At various levels, there are four lakes and a few mires containing organic lake sediments and peat.

Suursaari Island is the closest area where Estonian geologists are able to investigate the exposed crystalline basement. The first papers describing the geology and petrography of Suursaari Island were written by geologists from Tartu University, namely Hofmann (1841), Lemberg (1868) and Lagorio (1876). Ramsay (1892) compiled the first geological map of Suursaari Island at a scale of $1: 60$ 000. Berghell (1896) measured the altitudes of raised beaches and correlated them (without any micropalaeontological evidence) with the different stages of the Baltic Sea. Kurki (1915), in his geographical overview of Suursaari Island, also reported altitudes for the different shoreline deposits and features, and described the geomorphology of the island. Until now the most detailed data available about the Quaternary geology of Suursaari Island is that given by Sauramo (1958), who, in addition to shoreline measurements, gives the results of pollen analysis at three localities on the island. Preliminary results for the palaeogeographical and vegetation history of the island (Veski et al. 1995) and a checklist of diatoms found in three sediment sequences of Suursaari Island (Heinsalu 1997) have been published recently. 
Fig 1. Location and topography of Suursaari Island. Described lakes and mires are marked with black dots. Solid line A-B marks the position of the levelled profile from the Lehtisatama Bay to the slope of the Lounatkorkia Hill (Fig. 7).

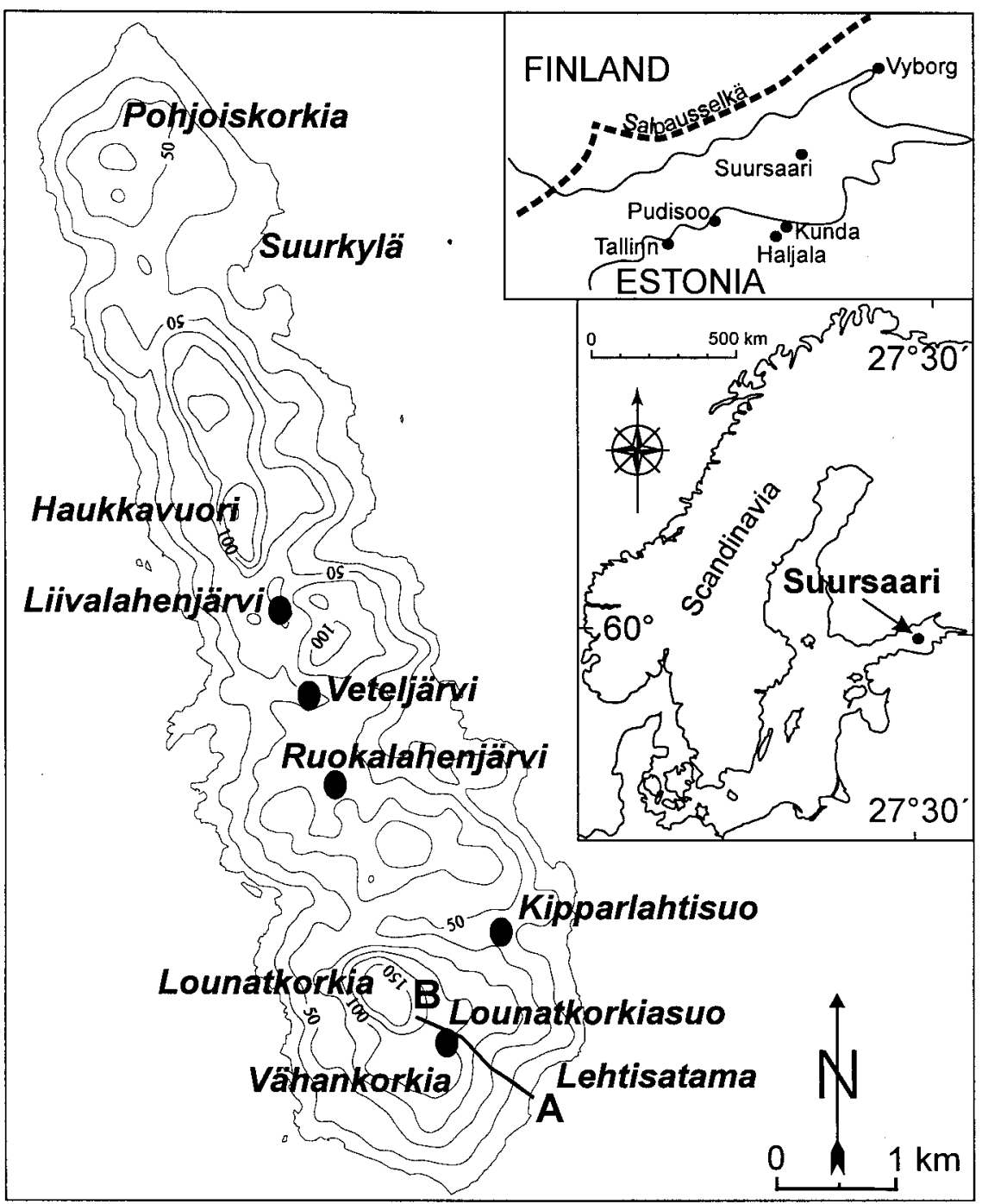

Table 1. Characteristics of the basins studied and methods applied on the investigated cores.

\begin{tabular}{|c|c|c|c|c|}
\hline & $\begin{array}{c}\text { Lounatkorkiasuo } \\
\text { Mire }\end{array}$ & $\begin{array}{c}\text { Lake } \\
\text { Ruokalahenjärvi }\end{array}$ & $\begin{array}{l}\text { Lake } \\
\text { Liivalahenjärvi }\end{array}$ & $\begin{array}{c}\text { Lake } \\
\text { Veteljärvi }\end{array}$ \\
\hline Latitude & $60^{\circ} 01^{\prime} 20^{\prime}, \mathrm{N}$ & $60^{\circ} 02^{\prime} 40^{\prime}, \mathrm{N}$ & $60^{\circ} 03^{\prime} 30^{\prime}, \mathrm{N}$ & $60^{\circ} 03^{\prime} 00^{\prime}, \mathrm{N}$ \\
\hline Longitude & $26^{\circ} 58^{\prime} 30^{\prime \prime} \mathrm{E}$ & $26^{\circ} 57^{\prime} 30^{\prime \prime} \mathrm{E}$ & $26^{\circ} 56^{\prime} 50^{\prime} \mathrm{E}$ & $26^{\circ} 57^{\prime} 00^{\prime \prime} \mathrm{E}$ \\
\hline Size $(\mathrm{m})$ & $130 \times 50$ & $350 \times 200$ & $400 \times 75$ & $250 \times 100$ \\
\hline Threshold altitude (m) & 96 & 58 & 45 & 40 \\
\hline Water depth $(\mathrm{m})$ & - & 4.4 & 1.1 & 2.5 \\
\hline Sediment depth $(\mathrm{m})$ & 3.5 & 7.3 & 7.4 & 4.6 \\
\hline Palaeoenvironmental analysis & $\mathrm{D}, \mathrm{P},{ }^{14} \mathrm{C}$ & $\mathrm{D}, \mathrm{P},{ }^{14} \mathrm{C}$ & $\mathrm{D},{ }^{14} \mathrm{C}$ & ${ }^{14} \mathrm{C}$ \\
\hline
\end{tabular}

$\mathrm{P}=$ pollen analysis, $\mathrm{D}=$ diatom analysis, ${ }^{14} \mathrm{C}=$ radiocarbon dating 


\section{METHODS}

Lake sediments were cored with a Russian peat sampler from a raft made of two rubber boats. Sediments were subsampled as $2 \mathrm{~cm}$ slices taken at $3 \mathrm{~cm}$ intervals and packed into plastic bags.

For diatom analysis the samples were treated with $30 \% \mathrm{H}_{2} \mathrm{O}_{2}$ at room temperature, and later at $50-60^{\circ} \mathrm{C}$, until all organic matter was removed. It was necessary to further treat some organic-rich gyttja samples with hot $10 \% \mathrm{HNO}_{3}$ and some drops of concentrated $\mathrm{H}_{2} \mathrm{SO}_{4}$. The diatom frustules were separated from the coarser and finer mineral matter by repeated decantation. In slide preparation Naphrax was used as the mounting medium. The analyses were carried out under a Leitz Diaplan microscope at 1250x magnification (N.A. = 1.25), using oil immersion and phase contrast. In each sample 400-500 non-Fragilaria spp. valves were counted. Because of mass occurrence in some of the samples, Fragilaria spp. is excluded from the base sum for the frequency calculations. Lycopodium tablets were added to a fixed weight of sediment (0.1-0.4 $\mathrm{g}$ dry weight) after digestion of organic matter from the Lounatkorkiansuo Mire sediment sequence in order to obtain information on palaeoproductivity and to express quantitatively diatom results. The following references were used in diatom identification: Hustedt (1930), Hustedt (1927-1964), Mölder and Tynni (1969-1973), Tynni (1975-1980), Krammer and Lange-Bertalot (1986-1991), Lange-Bertalot and Moser (1994) and Camburn and Kingston (1986). Diatom assemblages preserved in lake sediments give a good record of water pH history (Battarbee 1984). New methods using various statistical techniques have been developed for the reconstruction of past $\mathrm{pH}$ history (Braak \& Dam 1989, Birks et al. 1990). However, in the absence of calibration data for diatom assemblages from Suursaari Island, such methods cannot be used. Therefore, index B (Renberg \& Hellberg 1982) based on linear regression models and grouping of diatoms into $\mathrm{pH}$ preference categories has been used for the estimation of $\mathrm{pH}$ history. Although not a very precise method, it provides clear trends in changes of $\mathrm{pH}$ through time.
The pollen samples were prepared by the standard acetolysis method (Berglund \& Ralska-Jasiewiczowa 1986). Basal minerogenic samples were treated with heavy liquid $\mathrm{CdJ}_{2}+\mathrm{KJ}\left(2.2 \mathrm{~g} / \mathrm{cm}^{3}\right)$ to remove the mineral particles. About 500-700 arboreal pollen (AP) grains were counted for most of the spectra and in samples taken from the lowermost stratigraphic layers the AP sum remained around 300 pollen grains. Pollen percentages were calculated as AP + non-arboreal pollen $(\mathrm{NAP})=$ $100 \%$ (pollen sum). The percentages of other microfossils, such as pollen of aquatic plants (Aq), spores, algae and charcoal, were calculated from the pollen sum + the actual value for the certain microfossil $=100 \%$. The pollen and diatom diagrams were plotted using TILIA and TILIAGRAPH software (Grimm 1992). The organic content of the sediment was estimated from loss on ignition (LOI) at $550^{\circ} \mathrm{C}$ for 2 hours.

Conventional radiocarbon datings were carried out at the Institute of Geology, Tallinn Technical University (Tln) and Geological Survey of Finland (Su) and the accelerator mass spectrometry (AMS) dating at the Ångström Laboratory, Uppsala University (Ua). Radiocarbon dates are presented as uncalibrated ${ }^{14} \mathrm{C}$ years BP. Bulk sediment, soluble fraction (SOL) and/or insoluble fraction (INS) of the organic material has been used for dating.

Surveying the altitudes of shoreline deposits and the thresholds of lakes and mires was carried out using a levelling instrument (DAHLTA). All profiles were tied to the present sea level and corrected in accordance with sea-level measures at Suurkylä harbour. The levels of both the top and the bottom of the coastal formations were measured with the assumption that their bottom marks the former mean sea level.

\section{SEDIMENT CORES AND RADIOCARBON DATES}

\section{Lounatkorkiasuo Mire}

Lounatkorkiasuo Mire (Table 1) is situated in the southern part of the island, in a depression between Lounatkorkia and Vähänkorkia hills 
Table 2. Lithostratigraphy of the Lounatkorkiasuo Mire.

\begin{tabular}{cll}
\hline $\begin{array}{l}\text { Depth } \\
(\mathrm{cm})\end{array}$ & $\begin{array}{c}\text { Altitude } \\
(\mathrm{m} \text { a.s.1. })\end{array}$ & Sediment description \\
\hline $0-55$ & $95.5-96.0$ & Eriophorum-Sphagnum peat. \\
$55-150$ & $94.5-95.5$ & Woody Phragmites peat. \\
$150-251$ & $93.5-94.5$ & Phragmites peat, LOI >90\%. \\
$251-264$ & $93.4-93.5$ & Coarse detritus gyttja, brown, LOI 30-40\%. \\
$264-277$ & $93.2-93.4$ & Silty gyttja, greenish-brown, LOI 12-25\%. \\
$277-290$ & $93.1-93.2$ & Silt with plant macrofossils, LOI 6-9\%. \\
$290-305$ & $92.9-93.1$ & Sand with plant macrofossils, LOI 2-4\%. \\
$305-332$ & $92.7-92.9$ & Silt with plant macrofossils, LOI 2-4\%. \\
$332-350$ & $92.5-92.7$ & Sand, LOI <2\%. \\
\hline
\end{tabular}

Table $3 .{ }^{14} \mathrm{C}$ dates from Suursaari Island.

\begin{tabular}{|c|c|c|c|c|c|c|}
\hline Location & $\begin{array}{l}\text { Uncalibrated } \\
{ }^{14} \mathrm{C} \text { years BP }\end{array}$ & $\begin{array}{l}\text { Laboratory } \\
\text { code }\end{array}$ & $\begin{array}{l}\text { Depth } \\
(\mathrm{cm})\end{array}$ & $\begin{array}{l}\text { Altitude } \\
\text { (m a.s.1.) }\end{array}$ & $\begin{array}{c}\delta^{13} \mathrm{C} \% \\
\mathrm{PDB}\end{array}$ & Dated material \\
\hline $\begin{array}{l}\text { Lounatkorkiasuo } \\
\text { Mire }\end{array}$ & $9330 \pm 70$ & Tln-1711 & $240-250$ & & & peat, bulk \\
\hline $\begin{array}{l}\text { Lounatkorkiasuo } \\
\text { Mire }\end{array}$ & $9970 \pm 120$ & Tln-1718 & $252-262$ & & & coarse detritus gyttja, bulk \\
\hline $\begin{array}{l}\text { Lake } \\
\text { Ruokalahenjärvi }\end{array}$ & $8010 \pm 120$ & Tln-1606 & $895-900$ & $47.55-47.50$ & & gyttja, bulk \\
\hline $\begin{array}{l}\text { Lake } \\
\text { Ruokalahenjärvi }\end{array}$ & $9160 \pm 100$ & Ua-12760 & $966-968$ & $46.84-46.82$ & -22.6 & silty gyttja, SOL fraction \\
\hline $\begin{array}{l}\text { Lake } \\
\text { Liivalahenjärvi }\end{array}$ & $9610 \pm 50$ & Su-2822A & $750-760$ & $38.50-38.40$ & -24.1 & silty gyttja, SOL fraction \\
\hline $\begin{array}{l}\text { Lake } \\
\text { Liivalahenjärvi }\end{array}$ & $9570 \pm 50$ & $\mathrm{Su}-2822 \mathrm{~B}$ & $750-760$ & $38.50-38.40$ & -25.0 & silty gyttja, INS fraction \\
\hline $\begin{array}{l}\text { Lake } \\
\text { Veteljärvi }\end{array}$ & $9530 \pm 50$ & Su-2821A & $663-673$ & $36.57-36.47$ & -27.5 & silty gyttja, SOL fraction \\
\hline $\begin{array}{l}\text { Lake } \\
\text { Veteljärvi }\end{array}$ & $9440 \pm 70$ & $\mathrm{Su}-2821 \mathrm{~B}$ & $663-673$ & $36.57-36.47$ & -28.5 & silty gyttja, INS fraction \\
\hline
\end{tabular}

(Fig. 1). This small mire at $96.0 \mathrm{~m}$ a.s.l. is surrounded by Picea, Pinus, Betula and Alnus dominated forest with a field layer containing Salix, Juniperus, Calluna vulgaris and Empetrum nigrum. The sampling point is near the northern edge of the mire. Core was taken from a depth of $350 \mathrm{~cm}$, but the base of the sediment section was not obtained because of equipment failure. The whole core length recovered was analysed for pollen and diatom analysis was performed on the basal sediment sequence. The lithostratigraphy, from top to the bottom, is given in Table 2 .
Two radiocarbon dates were obtained from the sediments (Table 3 ). The basal $10 \mathrm{~cm}$ of the peat at $240-250 \mathrm{~cm}$ depth was dated to $9330 \pm 70$ uncalibrated ${ }^{14} \mathrm{C}$ years BP, whereas a sample from the topmost $10 \mathrm{~cm}$ of the coarse detritus gyttja at 251-261 cm depth, yielded an age of 9970 \pm 120 uncalibrated ${ }^{14} \mathrm{C}$ years BP.

\section{Lake Ruokalahenjärvi}

Lake Ruokalahenjärvi is the highest lake on Suursaari Island (Table 1). The lake is dystrophic and 
Table 4. Lithostratigraphy of Lake Ruokalahenjärvi sediment sequence.

\begin{tabular}{lcl}
\hline $\begin{array}{l}\text { Depth below } \\
\text { water surface }(\mathrm{cm})\end{array}$ & $\begin{array}{c}\text { Altitude } \\
\text { (m a.s.l.) }\end{array}$ & Sediment description \\
\hline $880-916$ & $47.3-47.7$ & Gyttja, brown, LOI 45-51\%. \\
$916-938$ & $47.1-47.3$ & Gyttja, green, LOI 35-39\%. \\
$938-963$ & $46.9-47.1$ & Silty gyttja, green, LOI 14-27\%. \\
$963-968$ & $46.8-46.9$ & Silt, green, LOI 10\%. \\
$968-972$ & 46.8 & Clay with plant macro-fossils, LOI 1-6\%. \\
$972-973$ & 46.8 & Clay, grey, LOI 1\%. \\
$973-974$ & 46.8 & Sand with gravel, grey, LOI 0.3\%. \\
$974-982$ & $46.8-46.7$ & Gravel. \\
\hline
\end{tabular}

Table 5. Lithostratigraphy of Lake Liivalahenjärvi sediment sequence.

\begin{tabular}{lcl}
\hline $\begin{array}{l}\text { Depth below } \\
\text { water surface }(\mathrm{cm})\end{array}$ & $\begin{array}{c}\text { Altitude } \\
\text { (m a.s.1.) }\end{array}$ & Sediment description \\
\hline $700-728$ & $38.7-39.0$ & Gyttja, green, LOI 30-34\%. \\
$728-760$ & $38.4-38.7$ & Silty gyttja, green, LOI 12-30\%. \\
$760-763$ & 38.4 & Silt, green, LOI 9\%. \\
$763-772$ & $38.3-38.4$ & Clay, grey, LOI 1-4\%. \\
$772-774$ & 38.3 & Fine sand, grey, LOI 0.1\%. \\
$774-794$ & $38.1-38.3$ & Sand with gravel, grey, LOI 0.2-0.4\%. \\
$795-800$ & $38.0-38.1$ & Gravel. \\
\hline
\end{tabular}

thermally stratified. Bare bedrock and a small quagmire surround the lake. Only part of the $730 \mathrm{~cm}$ sediment column was selected for palaeoenvironmental analysis and this included the basal transition from minerogenic to organic sediments. The lithostratigraphy of the investigated part of the sediment sequence is shown in Table 4.

The basal minerogenic sediments have clear boundaries while the transition to silty gyttja and gyttja is gradual without distinct boundaries. A sample of gyttja from a depth of $895-900 \mathrm{~cm}$ below the water surface has been dated to $8010 \pm 120$ uncalibrated ${ }^{14} \mathrm{C}$ years BP by conventional radiocarbon analysis. A bulk AMS date of $9160 \pm 100$ uncalibrated ${ }^{14} \mathrm{C}$ years BP (Table 3) at the lower boundary of silt is considerably younger than expected while the first date fits well with the rational limit of Alnus. The earlier AMS date might be explained by a very low sedimentation rate. Wohlfarth et al. (1998) have shown that the longterm storage of wet samples appears to significantly effect radiocarbon age and they obtained anom- alously young ages, even when the samples were kept cool. Fungi or micro-organisms may easily have been incorporated into the organic-rich medium and account for the large errors of several hundred to several thousand years.

\section{Lake Liivalahenjärvi}

Lake Liivalahenjärvi (Table 1) is a narrow N-S elongated dystrophic lake surrounded by mire. The lithostratigraphy of the investigated part of the sedimentary sequence, from top to the bottom, is shown in Table 5.

There is a gradual increase in LOI in the sediment stratigraphy from the depth of $763 \mathrm{~cm}$ upwards and, similarly, downwards there is step-bystep coarsening of the grain size in the core. The lowermost part of the silty gyttja at the depth of $750-760 \mathrm{~cm}$ is dated to $9610 \pm 50$ (SOL) and $9570 \pm 50$ (INS) uncalibrated ${ }^{14} \mathrm{C}$ years $\mathrm{BP}(\mathrm{Ta}-$ ble 3 ). 


\section{Lake Veteljärvi}

Lake Veteljärvi (Table 1) is a minor dystrophic lake surrounded by a small quagmire. The lowermost part of the silty gyttja, at a depth of 663.5$673.5 \mathrm{~cm}$, is dated to $9530 \pm 50$ (SOL) and $9440 \pm 70$ (INS) uncalibrated ${ }^{14} \mathrm{C}$ years BP (Table 3). The pre-isolation sediments are devoid of diatoms while the silty gyttja contains small-lake diatoms similar to those in Lake Liivalahenjärvi and Lake Ruokalahenjärvi.

\section{PALAEOENVIRONMENTAL ANALYSIS}

\section{Diatom record}

\section{Lounatkorkiasuo Mire}

The 254-348 cm core section was analysed for diatoms. Fig. 2 shows the most common diatom species and this section is divided into three diatom zones (DZ1-DZ3). A complete list of diatoms is given in Heinsalu (1997).

DZ1. 348-284 cm. - The diatom concentration is low $\left(1.3-8.7 \times 10^{6}\right.$ valves/g dry weight). Small Fragilaria spp. (mostly Fragilaria construens var. venter (Ehrenberg) Grunow and F. pinnata Ehrenberg) dominate and make up $43-84 \%$ of the diatoms. Periphytic Cymbella minuta Hilse, Navicula pseudoscutiformis Hustedt, N. laevissima Kützing, Achnanthes minutissima Kützing, Nitzschia frustulum (Kützing) Grunow and Pinnularia interrupta W. Smith are present in relatively high values. Planktonic diatoms are almost absent. The abundance of alkaliphilous diatoms is high.

DZ2. 284-264 cm. - The diatom concentration increases up to $25 \times 10^{6}$ valves/g dw. This assemblage remains characterised by high values of Fragilaria spp., but Fragilaria construens var. venter and $F$. pinnata decline and are replaced by F. exigua Grunow. Alkaliphilous diatoms become less abundant and the subdominant species of the previous zone either decrease in number or are absent. Circumneutral and slightly acidophilous diatoms like Cymbella gracilis (Ehrenberg) Kützing, $C$. incerta (Grunow) Cleve, C. naviculiformis Auerswald, and Brachysira neoexilis Lange-Bertalot appear.
DZ3. 264-254 cm. - The zone coincides with a coarse detritus gyttja. Diatom concentration is high in the lower part of the zone and decreases upwards. The assemblage is characterised by low values of Fragilaria spp.; Eunotia spp. is important and the number of acidophilous taxa increases.

\section{Lake Ruokalahenjärvi}

The basal part of the sediment column, between 974 and $880 \mathrm{~cm}$, was analysed. The profile is divided into three diatom zones (DZ1-DZ3). Diatoms are not preserved in the basal gravel (Fig. 3).

DZ1. 974-972 cm. - The sand contains few diatoms. Large-lake diatoms Aulacoseira islandica (O. Müller) Simonsen, Cymbella aspera (Ehrenberg) Peragallo, C. sinuata Gregory and Gyrosigma attenuatum (Kützing) Rabenhorst occur together with alkaliphilous and circumneutral periphytic small-lake diatoms Cymbella elginensis Krammer, Gomphonema truncatum Ehrenberg, G. coronatum Ehrenberg and Stauroneis phoenicenteron (Nitzsch) Ehrenberg.

DZ2. $972-963 \mathrm{~cm}$. - There is a $50 \%$ peak of Fragilaria spp. Large-lake diatoms have disappeared. The small-lake diatoms mentioned in the previous zone are at an optimum in the middle of the zone while these lessen towards its upper boundary. Planktonic diatoms are almost absent. The $\mathrm{pH}$ is slightly above 7 .

DZ3. 963-880 cm. - Small-lake diatoms characterise the assemblage. The amount of planktonic diatoms is consistently $20-30 \%$. Cyclotella comensis Grunow dominates. In the upper part of the zone Aulacoseira nygaardii Camburn and A. valida (Grunow) Krammer appear. Periphytic acidophilous taxa such as Brachysira brebissonii Ross, Eunotia spp., Frustulia rhomboides (Ehrenberg) De Toni, F. rhomboides var. saxonica (Rabenhorst) De Toni are common. The $\mathrm{pH}$ value decreases constantly.

\section{Lake Liivalahenjärvi}

Only the lower part of the sediment profile below $724 \mathrm{~cm}$ has been analysed (Fig. 4). The diatom 


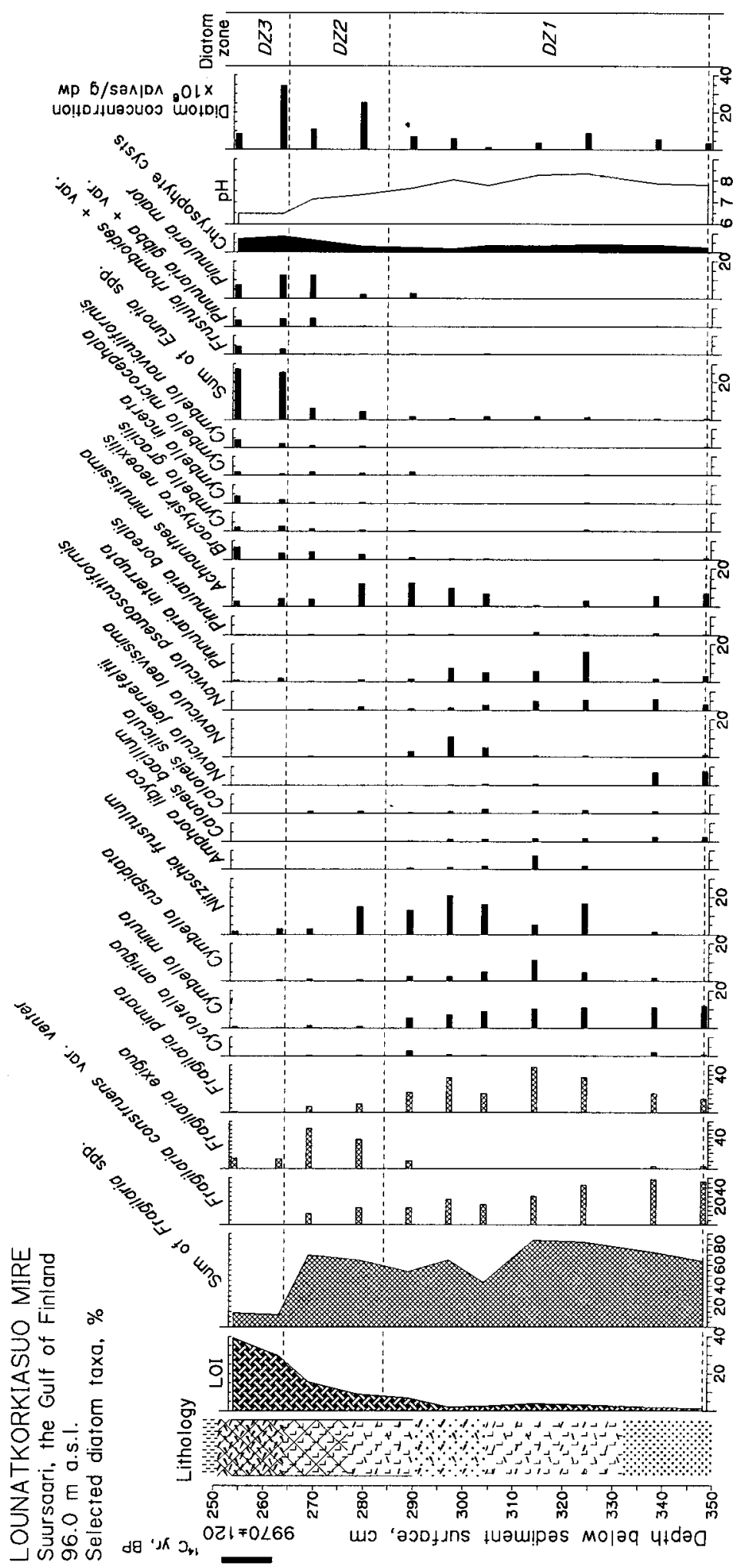

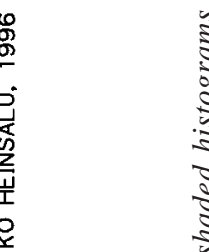




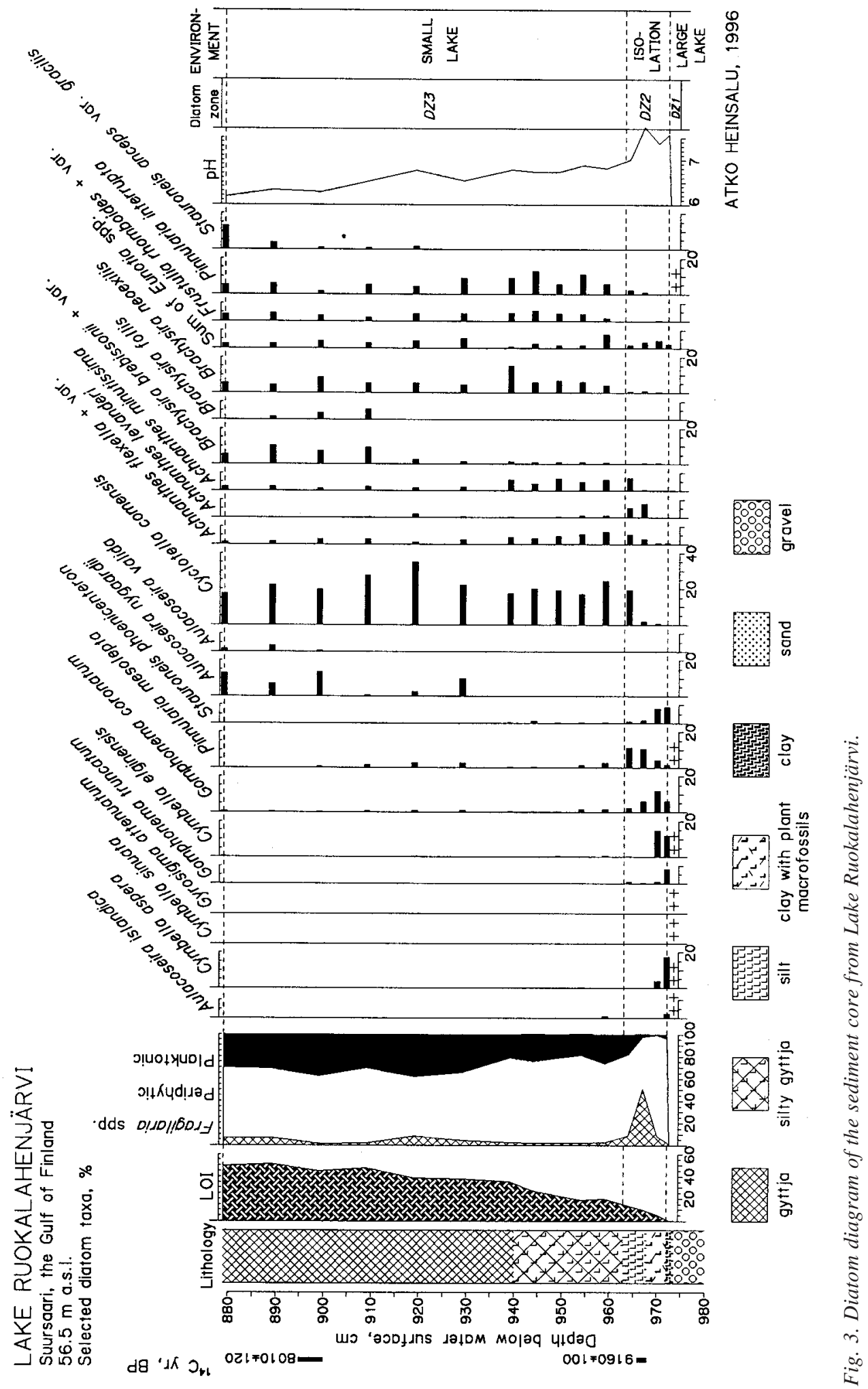




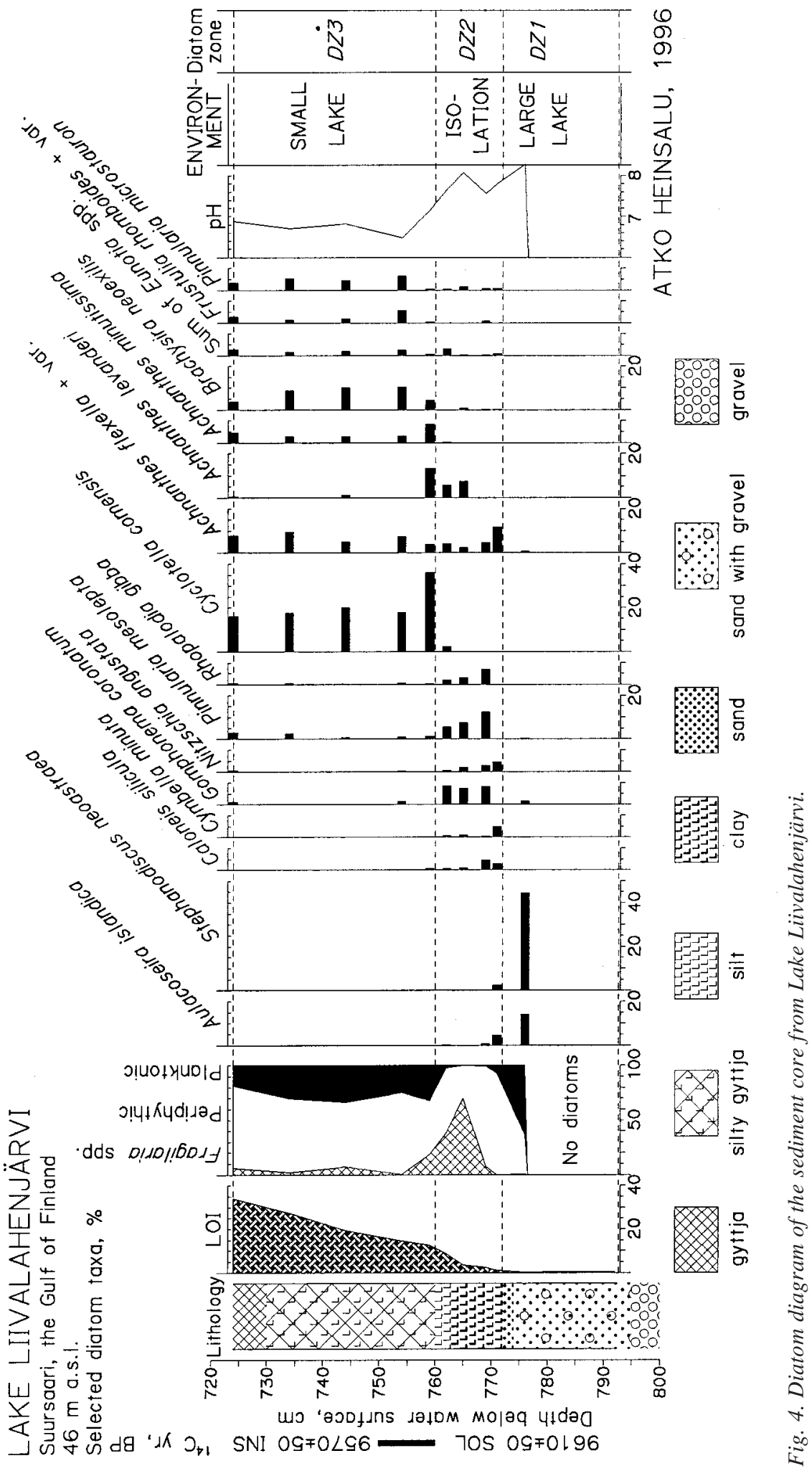


stratigraphy is very similar to that recorded in Lake Ruokalahenjärvi and also divides into three diatom zones (DZ1-DZ3). No diatoms were seen in the basal gravel.

DZ1. 776-772. - In the basal pre-isolation sand diatom analysis indicates predominantly large-lake planktonic diatom taxa, namely Aulacoseira islandica and Stephanodiscus neoastraea Håkansson \& Hickel.

DZ2. 772-760 cm. - Large-lake diatoms are absent in the clay and silt layers. Fragilaria spp., mostly F. construens (Ehrenberg) Grunow, F. construens var. venter and $F$. pinnata peak at $70 \%$ of the total sum. Alkaliphilous, small-lake periphytic diatoms such as Gomphonema coronatum, Caloneis silicula (Ehrenberg) Cleve and Nitzschia angustata Grunow, Rhopalodia gibba (Ehrenberg) O. Müller are present at relatively high abundances. The $\mathrm{pH}$ value is slightly above 7 .

DZ3. 760-724 cm. - In the silty gyttja alkaliphilous diatoms decline and small-lake diatoms such as Cyclotella comensis, Achnanthes flexella (Kützing) Brun, Brachysira neoexilis are common. The value of the $\mathrm{pH}$ decreases below 7 .

\section{Pollen record}

\section{Lounatkorkiasuo Mire}

The pollen diagram of the Lounatkorkiasuo Mire is divided into twelve local pollen assemblage zones (Fig. 5).

LKS-1. 347-334 cm. - Pinus and Betula dominate. Considerable amounts of Salix, Betula nanatype and Picea pollen grains occur in the zone. The NAP proportion is about $25 \%$, which is much less than in the other zones. Green algae Pediastrum ( $P$. boryanum as dominant) are present in the zone.

$L K S-2.334-305 \mathrm{~cm}$. - A major increase in NAP, up to over $60 \%$ of the total pollen sum, takes place. Artemisia, Chenopodiaceae, Cyperaceae and Ranunculaceae have their highest values. Most AP are Pinus.

LKS-3. 305-298 cm. - A maximum of Betula nana-type coincides with the start of a gradual decline of the NAP curve, mostly caused by the decrease of Artemisia, while Cyperaceae and Polygonum aviculare increase.

LKS-4. 298-264 cm. - Betula, Salix and Juniperus increase and the two latter culminate within that zone. At the upper zone boundary, there is a second maximum for Betula nana-type before a $60 \%$ increase in Betula. In the lower part of the zone, Cyperaceae and Poaceae are the dominant NAP while near the upper limit, Ericaceae (most probably Empetrum nigrum) expand. The summary Lycopodium curve also increases. Lycopodium selago was the only Lycopodium species in the previous zones. In this zone $L$. complanatum (dominant), L. clavatum and L. annotinum increase. Aquatic plants are represented by higher values.

LKS-5. 264-234 cm. - Betula and Pinus dominate, while Betula nana-type, Salix and Juniperus decline. Ulmus, Corylus and Alnus rise above $1 \%$. Picea, which had a continuous and relatively high curve in zones $1-4$, starts to decrease. The NAP curve is relatively low and mainly comprises Ericaceae, Poaceae and Cyperaceae. Calluna vulgaris appears in this zone. There are more spores of Polypodiaceae. The lower limit of the zone marks the end of the Pediastrum curve and an expansion in the Fungi hyphae curve (not shown on the diagram). The degree of destruction of pollen grains is higher than in the previous zones.

LKS-6. 234-206 cm. - This zone contains a maximum for Betula (75\%) and there is a corresponding minimum pollen curve for Pinus (below $4 \%$ ). The NAP curve oscillates between 10-30\%. Cyperaceae and Calluna occur and spores of Polypodiaceae have maximum values.

LKS-7. 206-182 cm. - Pinus increases to high values while Betula declines. The NAP proportion is relatively high with Ericaceae and grasses dominant. The Sphagnum curve has its first maximum.

LKS-8. 182-139 cm. - Alnus expands and culminates and there are also maxima of thermophilous QM (Ulmus, Tilia, Quercus, Fraxinus) and Corylus. The low, but continuous curve for Picea starts again and there are small increases in the relative abundance of Salix and Frangula. NAP is relatively low and the overall degree of preservation of grains is poor. 


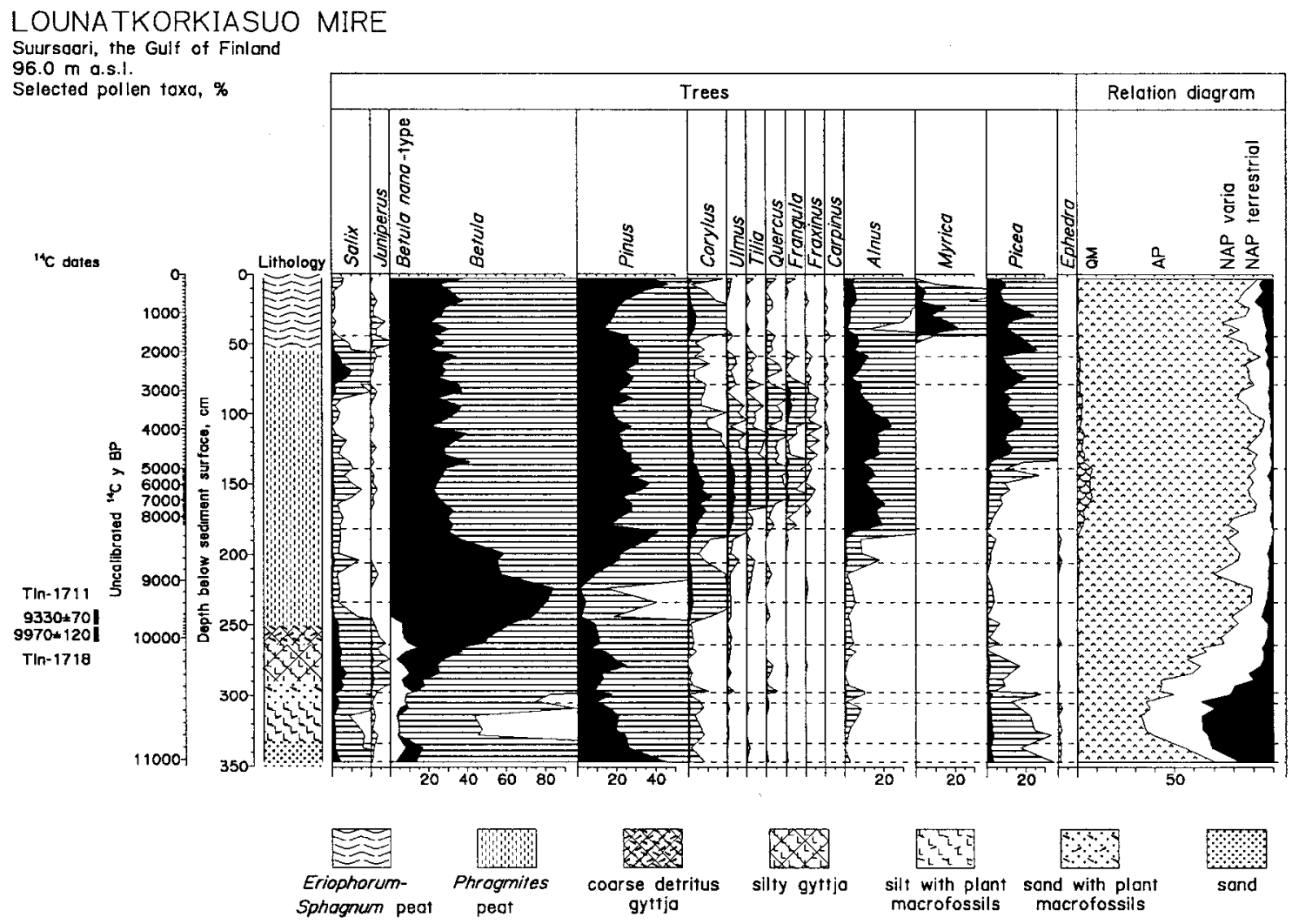

Fig. 5. Pollen diagram of the sediment core from the Lounatkorkiasuo Mire. Black curves represent the percentages and striped curves show the actual values multiplied by 10.

LKS-9. 139-79 cm. - The decline of $Q M$ and Corylus takes place at the lower zone boundary. Picea and Alnus increase their proportion of the pollen sum. Pinus and Betula values fluctuate from sample to sample, but the general trend is relatively stable. After the first Picea maximum Alnus declines and NAP is very low. There is a Frangula maximum and the destruction degree remains high.

LKS-10. 79-59 cm. -Salix and Picea values culminate in this zone. In the middle of the zone, the first pollen grains of Cerealia (Triticum-type) are registered, and from here the charcoal dust curve also increases. Pollen preservation improves and conifer stomata occur in this zone and the previous while their wider distribution takes place in the zone above.

$L K S-11$. 59-44 cm. - The highest values for
Picea, a relatively high amount of Pinus and a maximum for conifer stomata are registered in this zone.

$L K S-12.44-0 \mathrm{~cm}$. - The most significant feature of the zone is a high value for Myrica-type pollen which suppresses the pollen proportions for the other AP species. Generally the Pinus curve rises, Picea and NAP decline while Betula is stable. Corylus occurs in somewhat higher proportions than in the zones below.

\section{Lake Ruokalahenjärvi}

The pollen diagram of the basal part of Lake Ruokalahenjärvi sediment core is divided into four local pollen assemblage zones (Fig. 6).

RLJ-1. 970-957 cm. - Pinus and Picea dominate, and there are Betula, Betula nana-type and 


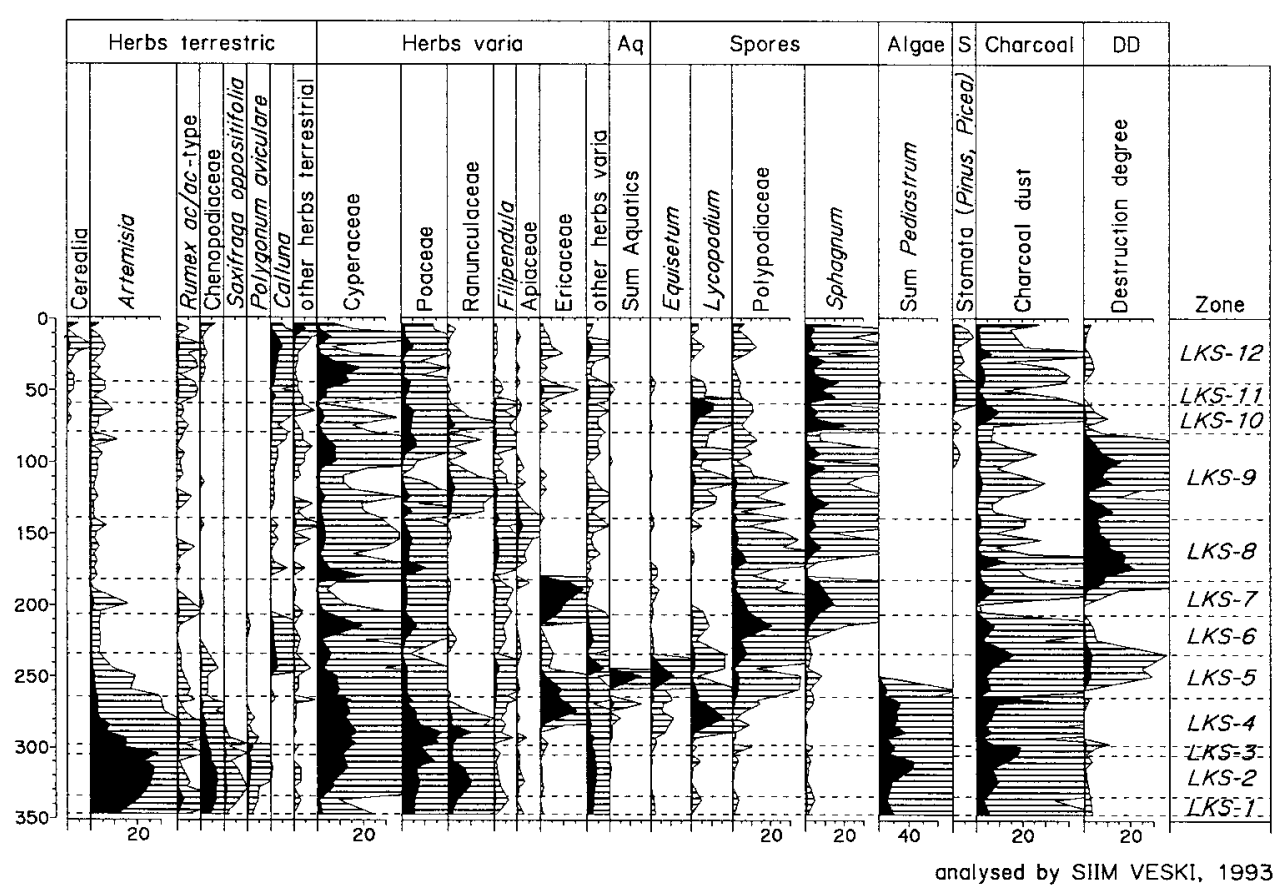

Salix pollen grains. The NAP proportion is about $20 \%$ in a single sample and rapidly decreases to below 10\%. Green algae Pediastrum (P. boryanum dominant) are present in the zone.

RLJ-2.957-932 cm. - Betula dominates while there is a large amount of Betula nana-type. The graphs for Ulmus and Corylus commence and there is a relatively large amount of NAP.

RLJ-3. 932-897 cm. - Pinus dominates.

$R L J-4.897-882 \mathrm{~cm}$. - The proportion of Alnus increases by $20 \%$.

As the pollen material from the Lounatkorkiasuo Mire is more complete, the zones of Lake Ruokalahenjärvi are correlated with the former as follows: LKS-4 and RKL-1, LKS-5-6 and RKL2, LKS-7 and RKL-3, LKS-8 and RKL-4.

\section{ANCIENT SHORELINES}

The ancient shorelines of the Baltic Sea on Suursaari Island are represented by accumulational boulder and pebble ridges, boulder, pebble and shingle fields, and abrasional cliffs and scarps. Sand dunes occur around Suurkylä in the northern part of the island. Raised shorelines are scattered and discontinuous and consequently correlation of them is sometimes complicated.

Sauramo (1958) has described the highest shoreline on Suursaari Island at $120 \mathrm{~m}$ a.s.l. along Haukkavuori. Solifluction processes often have disturbed shorelines between $90 \mathrm{~m}$ and $110 \mathrm{~m}$ a.s.l. The most significant of those are the beach ridges at $91 \mathrm{~m}$ and $95-96 \mathrm{~m}$ and the terraces with boulders and pebbles at around $109 \mathrm{~m}$ a.s.l. on the slopes of the Vähänkorkia and Lounatkorkia hills (Fig. 7). The isolation threshold of the Lounatkorkiasuo Mire is located immediately behind the coastal formations at $95.8 \mathrm{~m}$ a.s.1. There are ancient coastal formations at 84-87 m a.s.l. all over the island. The next distinct group of shorelines is situated at $60.5-64 \mathrm{~m}$ a.s.1. A few scarps and ridges occur between these pronounced shorelines (Table 6).

The next group of shorelines between $30 \mathrm{~m}$ and $58 \mathrm{~m}$ a.s.l. can be correlated with the stratigraph- 


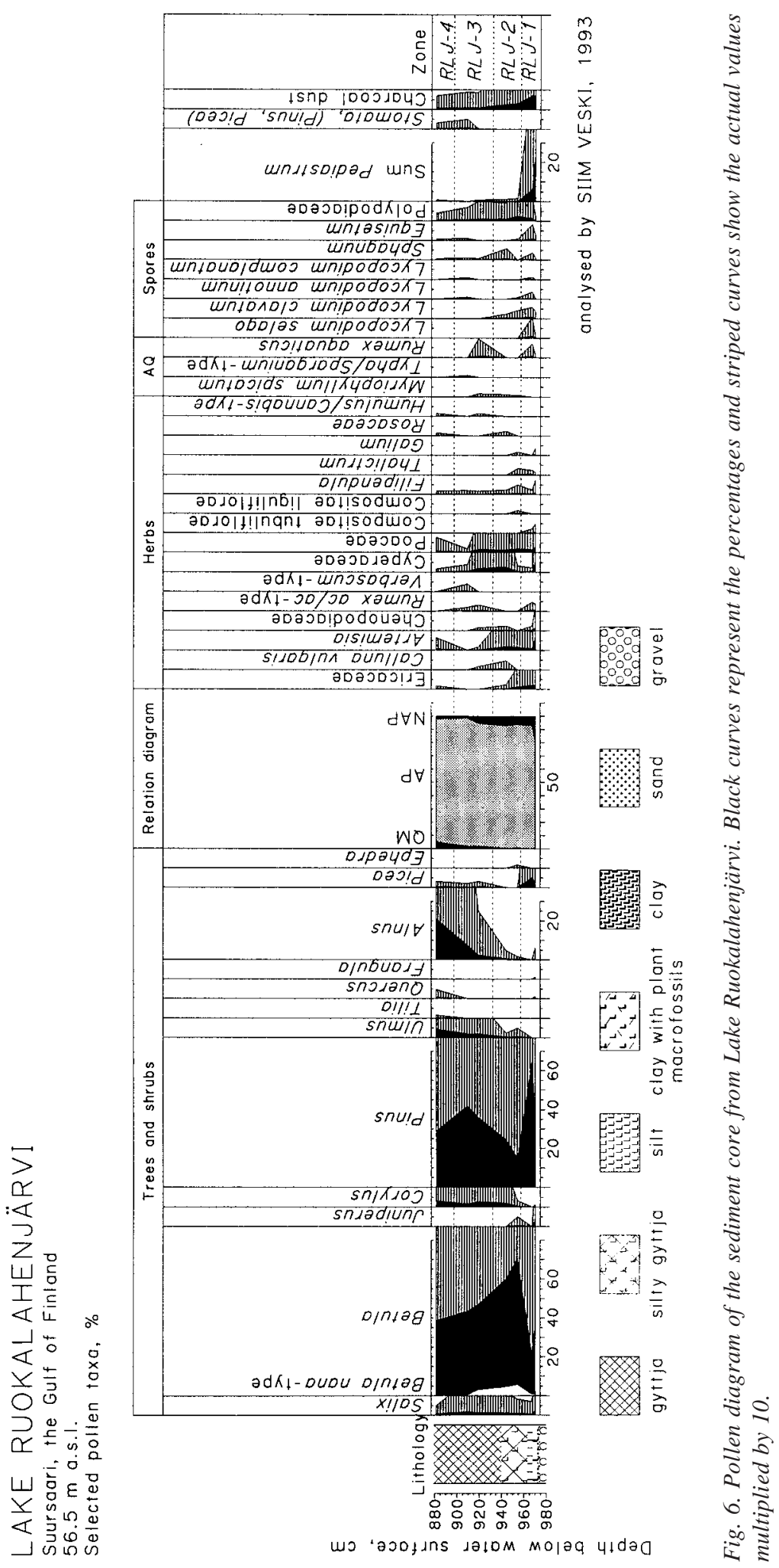




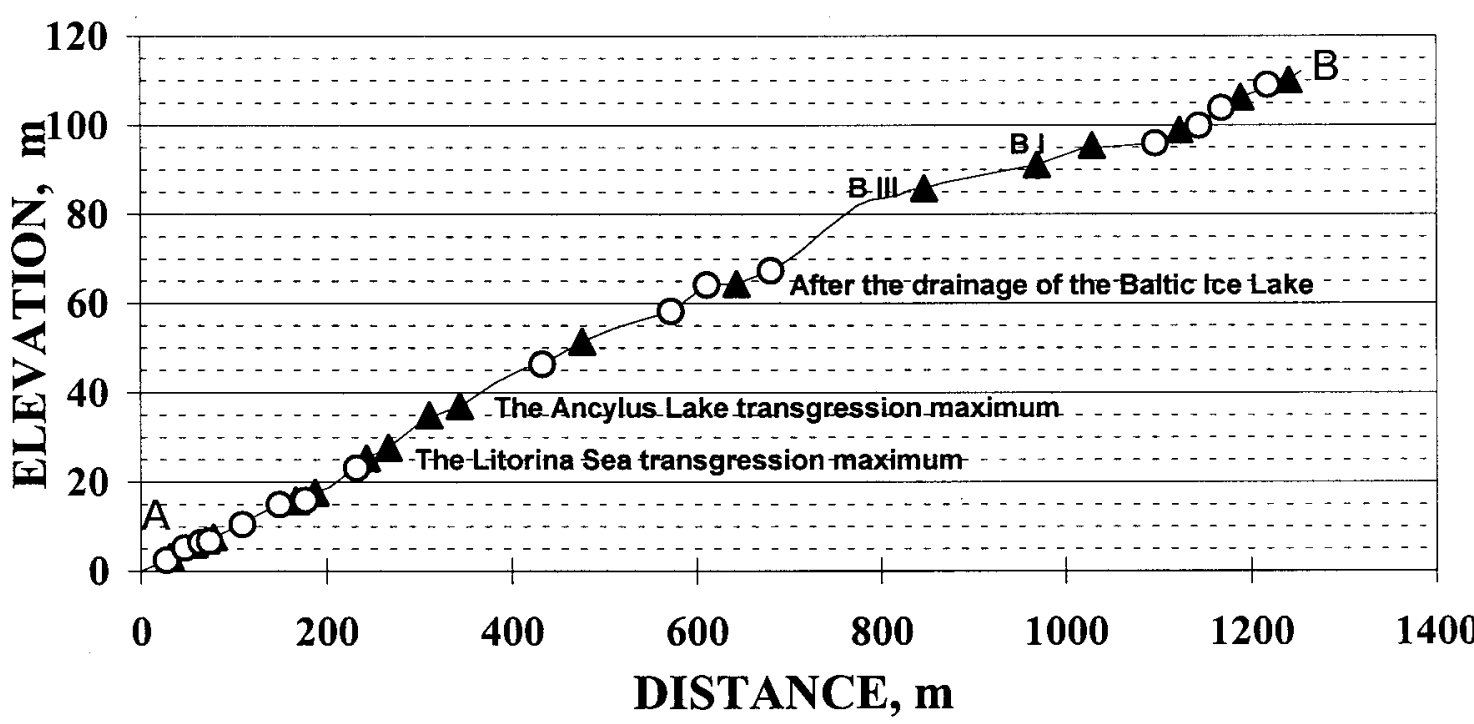

Fig. 7. Levelled profile A-B of coastal formations from the Lehtisatama Bay to the slope of the Lounatkorkia Hill. The triangles mark beach ridges and the circles mark abrasional cliffs and terraces. For the location of the levelled profile see Fig. 1.

Table 6. Altitudes of ancient coastal formations on Suursaari Island.

\begin{tabular}{|c|c|c|c|}
\hline $\begin{array}{l}\text { The stage of the } \\
\text { Baltic Sea }\end{array}$ & $\begin{array}{l}\text { Ancient shorelines } \\
\text { according Sauramo } \\
\text { (1958), m a.s.1. }\end{array}$ & $\begin{array}{c}\text { Levelled accumulational } \\
\text { coastal formations, } \\
\text { m a.s.l. }\end{array}$ & $\begin{array}{c}\text { Levelled abrasional } \\
\text { coastal formations, } \\
\text { m a.s.l. }\end{array}$ \\
\hline$?$ & 120 & $109.0,106.3,103.8,99.9$ & \\
\hline Baltic Ice Lake (B I) & 96 & $95.8,95.4$ & \\
\hline Baltic Ice Lake (B II) & & $91.1,91.2$ & \\
\hline $\begin{array}{l}\text { Baltic Ice Lake (B III) } \\
\text { before the drainage }\end{array}$ & 86,87 & $85.9,84.6$ & \\
\hline $\begin{array}{l}\text { Drainage of the Baltic } \\
\text { Ice Lake }\end{array}$ & $78,74,72$ & $81.9,79.7,77.3,73.7$ & $77.7,69.3,66.4$ \\
\hline
\end{tabular}

\begin{tabular}{|c|c|c|c|}
\hline $\begin{array}{l}\text { After the drainage of } \\
\text { the Baltic Ice Lake }\end{array}$ & $64,62,60$ & $64.1,60.6$ & 60.5 \\
\hline The Yoldia Sea & $50,47,46,43,42,40,39$ & $58.2,56.7,43.6,42,41.2$ & $57.5,50.8,46.7,46,38.8$ \\
\hline The Ancylus Lake & $37,34,33,32,30$ & $\begin{array}{l}36.7,35.2,34.4,33.2,32.2 \\
31.2,30.8,30.6,28.4,27.8\end{array}$ & $\begin{array}{c}37.0,35.0,34.9,31.8 \\
27.6,26.3\end{array}$ \\
\hline The Litorina Sea & $23,22,20,18,16$ & $\begin{array}{c}23.1,22.8,20.3,19,18.5 \\
18.1,17.6,16.7,16.4,15.5 \\
15,14.9\end{array}$ & $15.7,14.7$ \\
\hline The Limnea Sea & $14,12,11,9,6,5,4$ & $\begin{array}{c}13.4,12.4,10.4,9.9,9.7 \\
7.6,7.4,6.7,6.6,6.4 \\
6.2,5.5,5.2,3.9\end{array}$ & $8.3,7.5$ \\
\hline
\end{tabular}


ic records for lakes Ruokalahenjärvi, Liivalahenjärvi and Veteljärvi, and that for Kipparlahtisuo Mire, and it is likely that these belonged to the Yoldia Sea and the Ancylus Lake. The 36-37 m ridge is the most prominent of these shorelines. The shorelines below $23 \mathrm{~m}$ a.s.l. are mainly accumulational beach ridges and, in comparison with mainland shorelines, belonged to the Litorina Sea and the Limnea Sea (Table 6). Recent storms have formed those shorelines at $3.5-3.8 \mathrm{~m}$. The overlying ridges are covered by lichen, moss or vegetation and seem to be older.

\section{DISCUSSION}

\section{History of the Baltic Sea}

Shoreline features and palaeoenvironmental data can be used to reconstruct the history of the Baltic Sea following the last deglaciation. In the following text such a reconstruction is proposed. This is based on available evidence from Suursaari Island combined with the correlation of well-constrained events reconstructed elsewhere along the Baltic Sea basin. Correlation is based, successively, on three main types of evidence. The first type of evidence is correlation of raised shorelines on the island, based on their sequential altitudinal spacing, with elevated shorelines in Finland and Estonia. The second type is chronological and is based primarily on biostratigraphic correlation of the pollen assemblage zones and, second, on radiocarbon dating. The third type are local palaeoenvironmental indicators, such as diatom assemblage zones, that corroborate the general palaeogeographic context suggested by the reconstruction.

It is difficult to estimate when the higher parts of Suursaari Island were freed of ice cover during the last glaciation and emerged. Because of its height, the island may have been an obstacle to the flow of already thin ice cover during the final retreat. It is most likely that Suursaari Island was a nunatak during the deglaciation of the Gulf of Finland. Raukas (1986) and Karukäpp et al. (1992) have proposed that dead ice occupied the whole of the Gulf of Finland after the deglaciation of
Estonia. Therefore the evaluation of the origin and age of the highest shorelines on Suursaari Island is not straightforward. According to Sauramo (1958), the raised shore at $120 \mathrm{~m}$ a.s.l. on the slope of Haukkavuori Hill is disturbed by solifluction processes. However, all shorelines above $100 \mathrm{~m}$ a.s.l. are estimated to be of pre-Allerød or Allerød age and were probably associated with local icedammed lakes that formed during the retreat of the ice-sheet from the Gulf of Finland.

From the isolation threshold of the Lounatkorkiasuo Mire (96 m a.s.l.), shoreline features between 95-96 m can be dated approximately at the Allerød-Younger Dryas transition, which corresponds to the time of formation of the Salpausselkä I end moraines (Donner 1978). Therefore, the shoreline features correspond probably to the B I level of the Baltic Ice Lake. The B II level, which is c. $5 \mathrm{~m}$ lower than the B I level, formed during the ice margin retreat to Salpausselkä II end moraines (Donner 1969) and on Suursaari Island there is one such shoreline at $91-92 \mathrm{~m}$ a.s.l. The last high water level of the Baltic Ice Lake, named the B III level, corresponds to the phase at which the ice margin was stationary at Salpausselkä II, and is represented by those shorelines located c. $10 \mathrm{~m}$ below the B I (Donner 1969). Thus the B III level on Suursaari Island may be at $84.6-87$ $\mathrm{m}$ a.s.l. The end of the Baltic Ice Lake took place c. 10300 BP (Donner 1978, Svensson 1989) when ice recession at Billingen in south central Sweden resulted in its drainage. The water level dropped by 25-28 m (Donner 1982, Björck 1995, Glückert 1995) and the level of the Baltic Sea basin became equivalent to that of the ocean. On Suursaari Island, the pronounced shoreline group at 60.5$64 \mathrm{~m}$ a.s.1. is just $23-24 \mathrm{~m}$ lower than the B III level. According to Björck (1995), the main lowering of the Baltic Ice Lake to the level of the Yoldia Sea was a fairly rapid event lasting only a few years. There are some indications from the Finnish and Swedish shorelines (Donner 1978, Glückert 1977, Strömberg 1992) of a gradual lowering of the water level during drainage. The ancient shoreline data from Suursaari Island support the latter idea, as there are several minor coastal formations between the B III level and 60.5-64 m 
a.s.l. Sauramo (1958) has proposed that the shoreline at the altitude of $72 \mathrm{~m}$ a.s.l. on Suursaari Island marks the $g$ level, a $25 \mathrm{~m}$ lower water stand before the B I level. However, Fyfe (1990) and Donner (1992) have suggested that there is no direct evidence of a transgression before the water level stood at the B I level and the $g$ level was formed below water level.

Biostratigraphical records for lakes Ruokalahenjärvi, Liivalahenjärvi and Veteljärvi support data for shoreline displacement since the beginning of the Holocene. The isolation of Lake Ruokalahenjärvi is assumed to have occurred at the Younger Dryas-Pre-Boreal transition. The lower part of the pollen zone RKL-1 correlates well with the middle part of zone LKS-4 and this is supported by a ${ }^{14} \mathrm{C}$ date of $9970 \pm 120$ uncalibrated years BP from the Lounatkorkiasuo Mire (Figs. 5 and 6).

In Sweden, the Yoldia Sea has been divided into three phases according to palaeosalinity, with brackish-water conditions occurring during the middle phase (Svensson 1989, Wastegård et al. 1995). The Yoldia Sea formed at c. 10300 BP when the Baltic Ice Lake was finally drained and the levels of the ocean and the Baltic Sea basin became equal. However, freshwater conditions persisted for almost 300 years at the eastern coast of Sweden (Svensson 1991). The brackish phase of the Yoldia Sea has been estimated to lasted for 100 to 150 years (Svensson 1989) but there is some question if brackish waters reached the eastern part of the Baltic Sea basin. There is no clear answer to this from the diatom records available from Suursaari Island. Pre-isolation sediment of Lake Ruokalahenjärvi contains large-lake diatoms, such as Aulacoseira islandica, Gyrosigma attenuatum, Cymbella aspera and $C$. sinuata. It was isolated around $10000 \mathrm{BP}$, when brackish waters had not yet spread into the Gulf of Finland. Lake Liivalahenjärvi was isolated during the last phase of the Yoldia Sea before c. 9600 BP. According to Sauramo (1958), the basal fine sand/silt cored from the quagmire at Lake Liivalahenjärvi formed during the Pre-Boreal (Fig. 8). The diatom assemblage indicates that a freshwater environment prevailed around Suursaari Island at that time. This is indicated by the planktonic, large-lake diatoms Aulacoseira islandica and Stephanodiscus neoastraea.

However, we should consider that sediments from Suursaari Island allow us only a glimpse of the pre-isolation history. Suursaari Island is situated in the middle of the Gulf of Finland, and during persistent westerly winds, it is a significant obstruction to westward waves. Today the present storm shoreline on Suursaari Island is about 3-4 m above the actual sea level. Diatoms were absent from the bottom-most gravel of sediment profiles in all the lakes investigated. The probable cause of this is destruction of the frustules by strong wave action and transport out of the broken pieces by currents. The isolation of lakes is indicated in the sediment stratigraphy as a transition from sand to clay, and the disappearance of large-lake diatom taxa. Fragilaria spp. began to increase at the same time as the isolation. Fragilaria spp. often blooms around the isolation and appears to be dependent on a high nutrient supply (Stabell 1985). In this context, they are often termed as isolation indicators. Diatoms of the genus Fragilaria are often epipsammic, i.e. diatoms attached to sand and silt grains (e.g. Snoeijs \& Balashova 1998), and, in the sediment records of Suursaari Island, their number decreases when organic-rich sediment started to accumulate.

The lowermost part of the silty gyttja from Lake Veteljärvi, representing the sediment record after lake isolation, was dated to c. 9500 BP. A pollen analysis by Sauramo (1958) indicates that the ba-

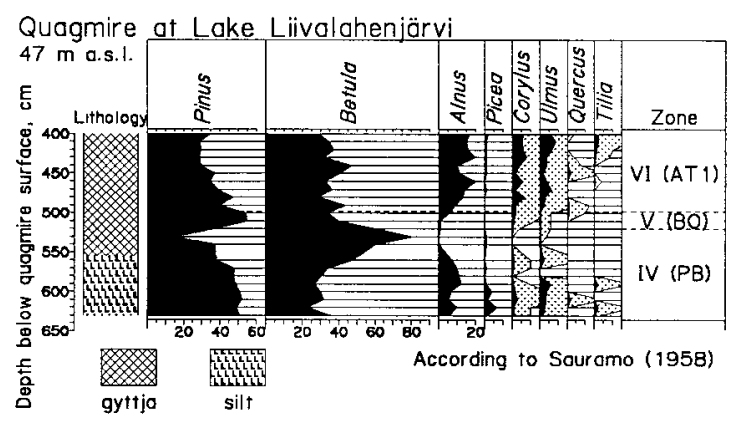

Fig. 8. Pollen diagram from the quagmire at Lake Liivalahenjärvi (according to Sauramo 1958). 


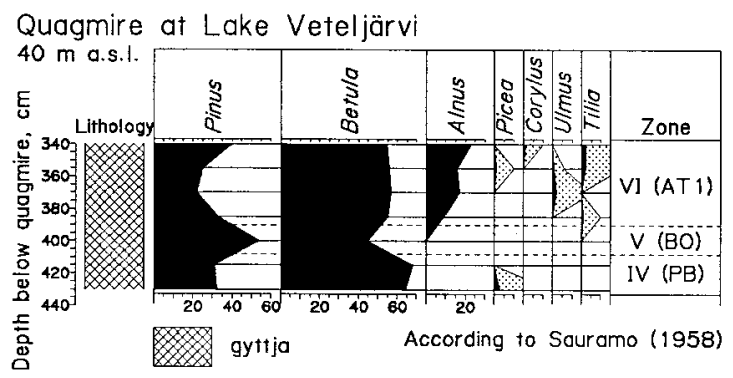

Fig. 9. Pollen diagram from the quagmire at Lake Veteljärvi (according to Sauramo 1958).

Kipparlahtisuo Mire

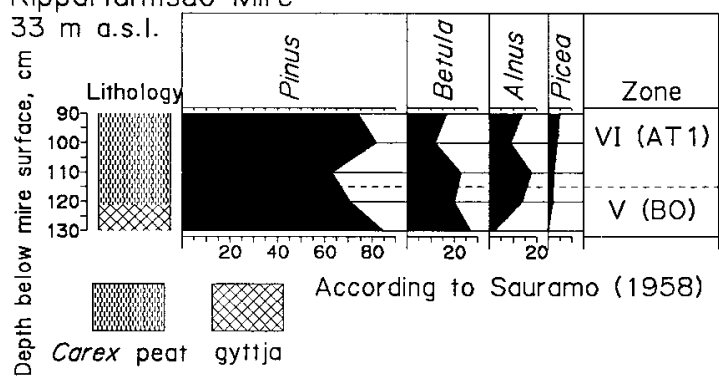

Fig. 10. Pollen diagram from the Kipparlahtisuo Mire (according to Sauramo 1958).

sal gyttja from the quagmire of Lake Veteljärvi formed during the Pre-Boreal (Fig. 9). The threshold altitude for this lake lies at $39.9 \mathrm{~m}$ a.s.l. We have no reason to question the validity of that date and, therefore, the numerous shorelines at 56$58 \mathrm{~m}, 50-52 \mathrm{~m}, 46-47 \mathrm{~m}$ and 41-44 $\mathrm{m}$ a.s.1. belong to the Yoldia Sea. We have no data how far down the Yoldia Sea regression reached on Suursaari Island. Near Tallinn, the Yoldia Sea minimum level could be estimated at $23 \mathrm{~m}$ a.s.l. (Veski 1998), and in the Vyborg area Dolukhanov (1979) has drawn the Yoldia Sea isobase at $20 \mathrm{~m}$ a.s.l. In southern Finland, the transgressional shoreline of the Ancylus Lake can still be traced at $70 \mathrm{~m}$ a.s.l., whereas in areas north of it, depending on the local land uplift, it is not present because the Ancylus Lake was regressive (Eronen 1983, Ristaniemi \& Glückert 1987). Therefore there is no reason to doubt that the Ancylus Lake transgression exceeded the minimum level of the Yoldia Sea on Suursaari Island.
The Kipparlahtisuo Mire is located at $33 \mathrm{~m}$ a.s.l. Alnus increases in the basal gyttja of the sediment profile (Fig. 10), and we hypothesise that this basin was isolated before alder inhabited the island. The expansion of Alnus has been dated to 8500 BP in northern Estonia (Saarse et al. 1998, Veski 1998). In southern Finland, the rational limit of Alnus has been dated to $8600 \mathrm{BP}$ (Donner et al. 1978) or 8300-8500 BP (Korhola \& Tikkanen 1991). The beginning of the Ancylus Lake is estimated at 9500 BP (e.g. Eronen 1976, Donner \& Eronen 1981, Glückert \& Ristaniemi 1982, Saarse et al. 1997) and the Ancylus Lake transgression culminated around 9200 BP (Ristaniemi \& Glückert 1987) or at 9000 BP (Eronen \& Haila 1982, Veski 1998). Thus the pronounced shoreline at 36-37 $\mathrm{m}$ a.s.l. may have formed by the culmination of the Ancylus Lake transgression.

The shoreline displacement curve for Suursaari Island (Fig. 11) is compared with the similar land uplift isobase areas on the mainland at Tallinn, Estonia (Kessel \& Raukas 1979, Veski 1998) in the southwest, and at Vyborg, Russia in the northeast (Saarnisto \& Grönlund 1996). The level of the Baltic Ice Lake prior to the final drainage on Suursaari Island was approximately $15 \mathrm{~m}$ higher than expected from the isobases (Svensson 1989, Donner \& Raukas 1992). The Ancylus Lake transgression maximum shoreline on Suursaari Island remains about $5 \mathrm{~m}$ higher than in the Vyborg area (Dolukhanov 1979) while differences in shoreline altitudes of the Litorina Sea have disappeared. According to Saari (1992), Suursaari Island lies in between two fracture zones. Probably Suursaari Island is a small downfaulted bedrock block, and anomalous shoreline altitudes on Suursaari Island can be explained by accelerated neotectonic land uplift during the late-glacial and early Holocene. Similar irregular isostatic uplift during the early Holocene has been recorded in western Sweden (Risberg et al. 1996).

\section{Palaeoenvironmental development of Suursaari Island}

The vegetational history has been mainly based on the Lounatkorkiasuo Mire data, complemented by 
Fig. 11. Shoreline displacement curves from Suursaari Island, Tallinn (according to Kessel \& Raukas 1979, Veski 1998) and Vyborg (according to Saarnisto \& Grönlund 1996). For the location of the sites see Fig. 1.

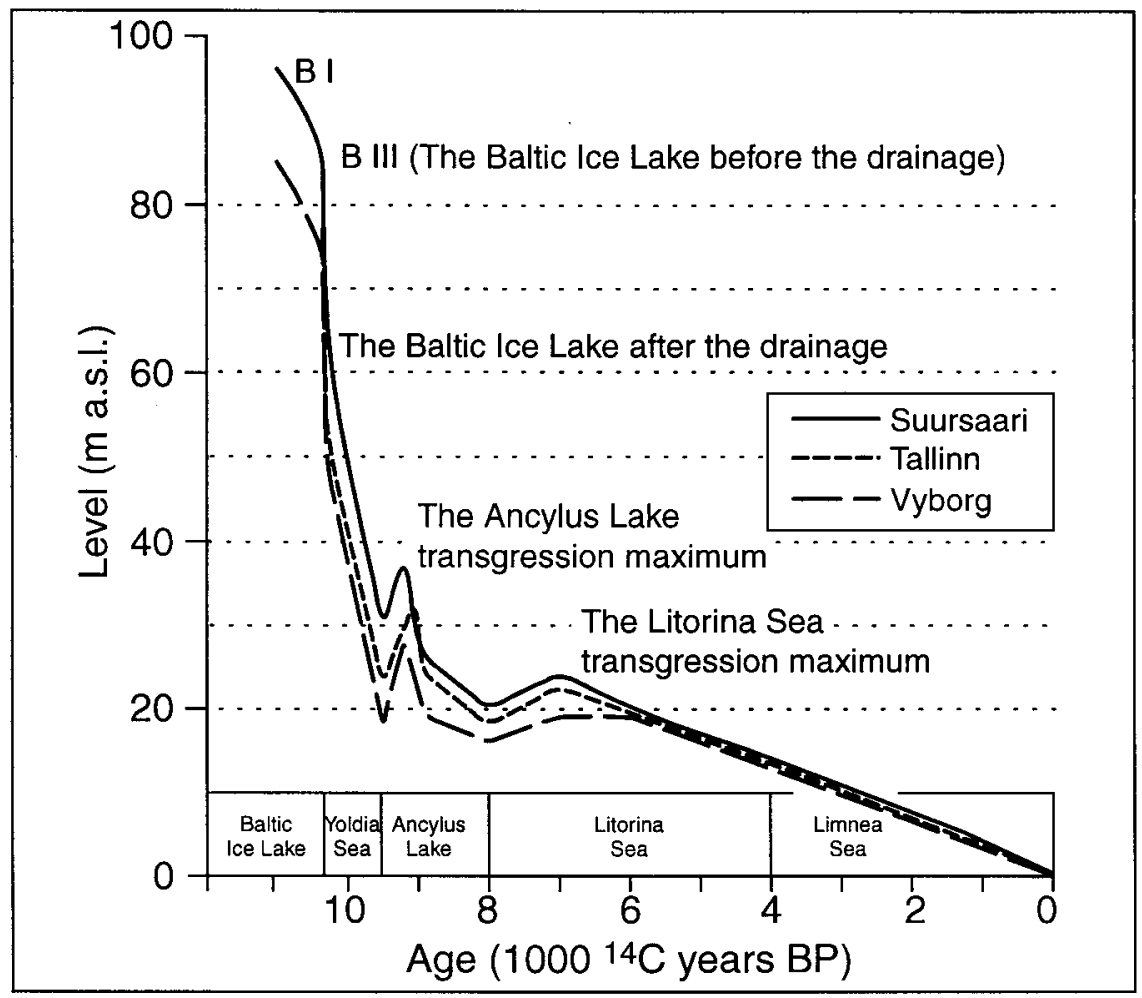

the material from Lake Ruokalahenjärvi and compared with diagrams presented by Sauramo (1958).

As suggested earlier (p. 36), Suursaari Island was most probably a nunatak during the final deglaciation of the Gulf of Finland. The bottom-most sand from the Lounatkorkiasuo Mire shows a dominance of AP over NAP in zone LKS-1. As zone LKS-2, with more than $60 \%$ of NAP, most probably correlates with the Younger Dryas, we assume that zone LKS-1 represents the late Allerød. Its sediment pattern, the presence of small-lake diatoms and the green algae Pediastrum indicate that the sheltered depression of the Lounatkorkiasuo Mire was occupied by a lake. In the late Allerød, Pinus, Betula and Salix stands spread in more sheltered locations, while higher areas around the Lounatkorkiasuo Mire clearly retained their tundra-like vegetation. The pine and birch pollen in the late Allerød sediments of the Lounatkorkiasuo Mire could also be explained by long distance aeolian transport to the site from more southern localities, as shown by Aario
(1940) for the barren landscape of Finnish Lapland. In this example Betula nana and Salix polaris were probably the only arboreal pollen producers in the area.

The proportion of Picea is quite significant in the Allerød and Younger Dryas. The presence of Picea in the Allerød forest on the Estonian mainland has been widely discussed. Near Kunda, North-Estonia, Thomson $(1929,1935)$ found pollen grains of Picea at values close to $30 \%$ and spruce needle macrofossils in the layers that he correlated with the Allerød. The complex discussed was later correlated with the end of the Younger Dryas (Raukas 1986). Picea remains significant at Haljala, 15 km SW from Kunda (Männil \& Pirrus 1963, Raukas 1986), and at more southern localities in Estonia (Pirrus 1969, Saarse et al. 1995, 1999). On Suursaari Island Picea has low and even values during the late Allerød, as well as in the Younger Dryas. Possibly, the locality was too northerly and severe for spruce (as well as for Alnus and Corylus) and the pollen was 


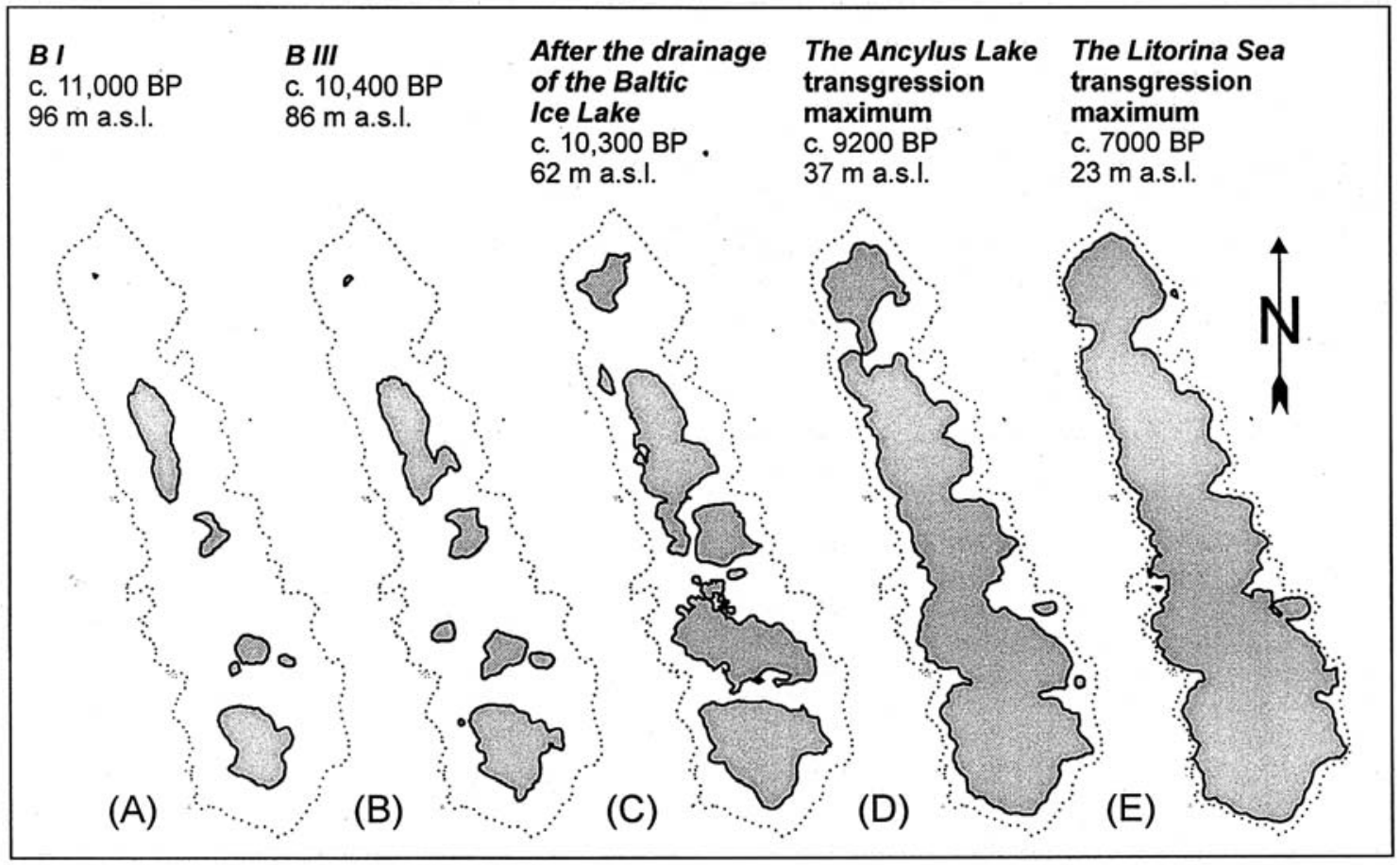

Fig. 12. Palaeogeography of Suursaari Island. A. Allerød/Younger Dryas shoreline. B. The Baltic Ice Lake shoreline prior to the drainage. C. Shoreline after the drainage of the Baltic Ice Lake. D. The Ancylus Lake transgression maximum shoreline. E. The Litorina Sea transgression maximum shoreline.

brought from the south by long distance air transport to the site, or out-washed into the basin from till. However, there is no overwhelming evidence on the Estonian mainland for the previous statement about Allerød spruce because the majority of the Allerød sites are sub-aquatic and parts of larger basins, in which there was considerable redeposition and washout of pollen grains from glacial deposits. Nevertheless, as Kullman (1996) has shown in central Sweden, spruce could have been present much earlier than its pollen record suggests.

During the Late Weichselian, the Salpausselkä foreland and large territories of northern Estonia were submerged and, consequently, dry land sites for pollen analysis are available in central Estonia and in the southeastern foreland of the Salpausselkä (Tolonen 1967, Hyvärinen 1971). Hyvärinen (1973), however, admits that the supraaquatic pollen floras correspond well with those of the subaquatic Younger Dryas sites (Tynni
1966, Repo \& Tynni 1967, 1969). The supra- and sub-aquatic Younger Dryas pollen floras in Estonia are also well correlated (Pirrus 1969). However, with increasing age sediments tend to contain more rebedded pollen grains making their stratigraphical subdivision extremely complicated. It could well transpire that the lower parts of the North-Estonian Allerød sites, such as Haljala, Pudisoo and Tallinn (Fig. 1), are of doubtful stratigraphic value due to the relative closeness of the ice marginal zone.

During the Allerød-Younger Dryas transition, the water level was about $96 \mathrm{~m}$ a.s.l. and the highest parts of the present island of Suursaari formed an archipelago of seven islets with tundra vegetation; the northern tip, Pohjoiskorkia, being only a bare rock some metres above the water surface (Fig. 12A).

Zone LKS-2, correlated with the Younger Dryas, begins with the establishment of tundra vegetation on the whole island (correlated with the 
NAPa zone of Hyvärinen 1971) with ArtemisiaChenopodiaceae-Ranunculaceae-Saxifraga oppositifolia-Polygonum aviculare dominating. Correlation with Finnish vegetation data rather than with Estonian data is more relevant when the type of bedrock is considered. The main differences in the vegetation history between southeastern Finland and Suursaari Island are time transgressive. The NAPc zone of Hyvärinen (1973) belongs to the Pre-Boreal. The Lycopodium sub-zone (Hyvärinen 1973), contemporaneous with the birch maximum in southern Finland, has been correlated with zone LKS-4 in the Lounatkorkiasuo Mire. If this is not the case, the vegetation development has gone through the same phases as in southern Finland, which, because of the earlier deglaciation, have been somewhat earlier on the island of Suursaari.

The initial development of the Lounatkorkiasuo Mire basin as a small pool is characterised by an alkaline freshwater environment. Inwashing of minerogenic particles from the steep slopes of the surrounding hills resulted in increased input of base cations. The presence of periphytic diatoms common in arctic lakes (e.g. Cymbella minuta, C.cuspidata, Nitzschia frustulum, Navicula pseudoscutiformis and $N$. laevissima) indicate a cold climate. Fragilaria spp. often dominate in the sediments of recently deglaciated areas (Haworth 1976) and in Antarctic lakes (Wasell \& Håkansson 1992, Jones 1993). Small Fragilaria spp. are often competitive on sandy and silty habitats (Kingston 1984). Because of their higher turnover rates, these small-celled diatoms may quickly form blooms and outcompete larger diatoms with slower growth rates during the brief growing season in arctic lakes (Lotter et al. 1999). At the same time, the almost complete absence of planktonic diatoms in diatom zone 1 may indicate extensive ice cover and a short ice-free season (Douglas \& Smol 1999). Cyclotella antiqua prefers both littoral and pelagic environments (Krammer \& Lange-Bertalot 1991). The low diatom concentration can be explained by either severe climatic conditions and/or a sediment accumulation rate that was higher in diatom zone 1 with diatoms becoming relatively diluted in the sediment ma- trix. Therefore, increases in diatom concentration in diatom zone 2 may be explained by a smaller rate of accumulation. Fragilaria exigua, the dominant diatom in the zone, has a $\mathrm{pH}$ optimum below 7 (Korsman \& Birks 1996). The diatom-recorded decrease in $\mathrm{pH}$ may be the effect of depletion of $\mathrm{pH}$-buffering compounds in the catchment and reduction of erosion from the hillslopes.

Subsequently the predominantly Artemisia-tundra is more widely inhabited by Betula nana in zone LKS-3 (NAPb zone in Hyvärinen 1973) and there is a change in the NAP composition. Prior to the final drainage of the Baltic Ice Lake about 10400 BP, the archipelago of Suursaari consisted of eight islets (Fig. 12B). While Artemisia decreased, other arctic species, such as Cyperaceae, Poaceae and Rumex, expanded. According to Hyvärinen (1971), the grass and sedge phase may be quite short and of transitional origin because the deposits consist of comparatively coarse sediments whose relative age may be exaggerated by a rapid sedimentation rate. Afterwards the climate gradually improved, Juniperus and Salix immigrated forming a low shrub tundra with Empetrum nigrum and sedges in zone LKS-4 (NAPc in Hyvärinen 1971). The more sheltered southern slopes offered a reasonably favourable site for the developing open birch forest; the Lycopodium peak being associated with this environment before the invasion of the field layer by ferns in more wet areas.

Increasing LOI values at $10000 \mathrm{BP}$ indicate an increase in autochthonous productivity in the Lounatkorkiasuo Mire basin and, consequently, a change to more dystrophic conditions is clear. The abundance of Eunotia spp., diatoms that often expand in bog-pools and among mosses, suggests paludification and infilling of the lake. The final drainage of the Baltic Ice Lake caused a rapid regression of the water level (about $25 \mathrm{~m}$ ) and created virgin rock surfaces suitable for colonisation by vegetation. At the Late Weichselian/Holocene boundary (10 $000 \mathrm{BP})$, when the water level was about $58.5 \mathrm{~m}$ a.s.1., Lake Ruokalahenjärvi was isolated from the main basin (Fig. 12C). In a short period during the Pre-Boreal chronozone (between 10000 and $9000 \mathrm{BP}$ ), the rest of the lake basins 
were isolated, and the island of Suursaari no longer had an archipelago setting (Fig. 12D).

The beginning of the Pre-Boreal is clear from lithostratigraphy and it also records a marked change in vegetation development. A thin peat layer at $264 \mathrm{~cm}$ separated the lower silty gyttja and the overlying coarse detritus gyttja, which no longer contained Pediastrum, and was transformed into a Phragmites peat at the depth of $251 \mathrm{~cm}$. In the Pre-Boreal, the forest tundra vegetation changed rapidly into birch forest with ferns in the field layer. The former lake basin became overgrown and peat accumulation started. The lightdemanding AP species gradually vanished, as $U l$ mus and Corylus made their first efforts to establish themselves on the island. At the end of the Pre-Boreal, birch had occupied every possible growing place and the landscape became somewhat closed as Pinus and local NAP diminished to almost negligible amounts. This event is better observed at higher elevation areas in the Lounatkorkiasuo Mire, whereas in lower, elevated parts of the island, the sea-level fluctuations created open surfaces for pine colonisation. The maximum occurrence of birch in the Lake Ruokalahenjärvi zone RKL-2 is correlated with zones LKS-5 and LKS-6.

The catchment areas of the lakes on Suursaari Island are small and consist mostly of bare crystalline bedrock. The isolation sediments of lakes Ruokalahenjärvi and Liivalahenjärvi are characterised by alkaliphilous diatoms. After the isolation in the early Holocene, weathering material and available leachable mineral nutrients from the catchment were transported into the lake basins, which may explain the relatively high $\mathrm{pH}$ level. During that period, clay and silt were deposited. Higher initial nutrient and $\mathrm{pH}$ levels can be explained alternatively by "remnant" pre-isolation water, which persisted during the water retention time. The alkaliphilous diatom flora was soon replaced by small-lake, circumneutral and acidophilous taxa, and the $\mathrm{pH}$ sharply decreased. The floristic shift meant a change in oligotrophic conditions and paludification of the basin margins led to dystrophication of the lakes. The rapid $\mathrm{pH}$ decrease and oligo-dystrophication indicate that the catchment was depleted of nutrients and weathering, and that soil leaching became relatively insignificant in nutrient supply to the lakes.

In the zone LKS-7 (correlated with the Boreal chronozone), Pinus invades the area together with Ericales in the field layer. The climate and the soil cover soon improved enough to allow first Alnus and then $Q M$ and Corylus to establish themselves on the slopes surrounding the mire. The pollen diagram suggests that these species appeared at the same time. Most probably this happens due to the very low sedimentation during the climatic optimum (zone LKS-8). Since the immigration of $\mathrm{Al}$ $n u s$ and the $Q M$, the forest around the Lounatkorkiasuo Mire became dense and pollen productive, for we do not see exotic pollen grains (e.g. Ephedra) any longer. This also means that, compared to Lake Liivalahenjärvi (Sauramo 1958), the vegetation history can only be established for a very small area because of the expansion of Alnus. Salix, Frangula alnus, Alnus and Betula probably inhabited the wetter areas during the climatic optimum, while $Q M$ and Corylus surrounded the basin. The slopes of the Lounatkorkia Hill rise considerably above the mire offering suitable growing habitats for pine and birch - their proportion in vegetation remains fairly important during the climatic optimum. As the landscape was generally closed and the climate mild there are no drastic differences in the vegetation of the lower and higher elevated parts of the island that developed during the climatic optimum. The make-up of the island had quite a similar form to that seen at present (Fig. 12E).

Climatic deterioration after the climatic optimum (correlated with the Atlantic/Sub-Boreal boundary at $5000 \mathrm{BP}$ ) affected the $Q M$ and $\mathrm{Co}$ rylus stands, and Picea established itself on the island. The opposite behaviour of pine and alder reflected differences between the high and the low parts of the island. In low areas Pinus dominated and Picea and Alnus decreased remarkably. In contrast, in the Lounatkorkiasuo Mire, Alnus attained its widest distribution during the Sub-Boreal (zone LKS-9). The Picea maxima coincide with low herbaceous plant proportions, thus the actual local vegetation history represents periods 
of a more closed Picea forest and somewhat more open Betula-Picea forest. Picea also affected the $Q M$, which decreased during periods of spruce expansion. Frangula, Salix, Myrica (zone LKS12), Juniperus and Corylus gained locally improved growing conditions between the spruce expansions. Prehistoric human interference on the landscape started at zone LKS-10, and increased, but it still remained comparatively low, as the island was not very suitable for agriculture.

\section{CONCLUSIONS}

1. The oldest analysed sediments on Suursaari Island from the Lounatkorkiasuo Mire at $96 \mathrm{~m}$ a.s.l. deposited during the late Allerød. Lateglacial vegetation development went through the same phases as in southern Finland, however these are probably somewhat earlier on the Island of Suursaari. There are differences in the Holocene vegetation history of the higher and lower areas of the island.

2. Lake Ruokalahenjärvi was isolated around $10000 \mathrm{BP}$ during the initial phase of the Yoldia Sea and diatom assemblage indicates that at that time brackish-water flow had not penetrated into the Gulf of Finland. Diatoms from the isolation sediments of Lake Liivalahenjärvi and Lake Veteljärvi indicate a freshwater environment for the Yoldia Sea final phase at 9500-9600 BP.

3. Late Weichselian and early Holocene ancient shorelines on Suursaari Island lie 5-15 m higher than expected from the isobasis of similar land uplift areas on the mainland. The anomalous shoreline altitudes on Suursaari Island may be explained by irregular land uplift. By the time of the Litorina Sea differences in shoreline altitudes had disappeared.

\section{ACKNOWLEDGEMENTS. This research was sup-} ported by the Maj and Tor Nessling Foundation, the Nordic Council of Ministers, the Baltic Emergency Fund and grant No. 3222 of the Estonian Science Foundation. We wish to thank our colleagues who helped us during the fieldwork.
H. Håkansson and T. Grönlund gave many helpful comments on diatom taxonomical problems. We are indebted to R. Rajamäe, T. Kankainen and G. Possnert for the radiocarbon dates. E. Paavilainen and E. Mäkeläinen carried out the loss of ignition analysis at the Geological Survey of Finland, Espoo. M. Bouchard and J. Smol corrected some of the English and constructive comments by M. Saarnisto and J. Risberg improved the manuscript.

\section{REFERENCES}

Aario, L. 1940. Waldgrenzen und Subrezenten Pollenspektren in Petsamo, Lappland. Annales Academiae Scientiarum Fennicae, Ser. A, 54, 1-120.

Åker, K., Eriksson, B., Grönlund, T. \& Kankainen, T. 1988. Sediment stratigraphy in the northern Gulf of Finland. In: Winterhalter, B. (ed.) The Baltic Sea. Geological Survey of Finland, Special Paper 6, 101-117.

Battarbee, R.W. 1984. Diatom analysis and the acidification of lakes. Philosophical Transactions of the Royal Society, London B 305, 451-477.

Berghell, H. 1896. Bidrag till kännedomen om Södra Finlands kvartära nivåförändringar. Bulletin de la Commission géologique de Finlande 5, 1-64.

Berglund, B.E. \& Ralska-Jasiewiczowa, M. 1986. Pollen analysis and pollen diagrams. In: Berglund, B.E. (ed.) Handbook of Holocene Palaeoecology and Palaeohydrology. Chichester: John Wiley \& Sons, 455-484.

Birks, H.J.B., Line, J.M., Juggins, S., Stevenson, A.C. \& Braak, ter C.J.F. 1990. Diatoms and $\mathrm{pH}$ reconstruction. Philosophical Transactions of the Royal Society, London B 327, 263-278.

Björck, S. 1995. A review of the history of the Baltic Sea, 13.0-8.0 ka BP. Quaternary International 27, 19-40.

Braak, ter C.J.F. \& Dam, van H. 1989. Inferring pH from diatoms: a comparison of old and new calibration methods. Hydrobiologia 178, 209-223.

Camburn, K.E. \& Kingston, J.C. 1986. The genus Melosira from soft-water lakes with special reference to northern Michigan, Wisconsin and Minnesota. In: Smol, J.P., Battarbee, R.W., Davis, R.B. \& Meriläinen, J. (eds.) Diatoms and Lake Acidity. Dordrecht: Dr W. Junk Publishers, 17-34.

Dolukhanov, P.M. 1979. The Quaternary history of the Baltic. Leningrad and Soviet Karelia. In: Gudelis, V. \& Königsson, L.-K. (eds.) The Quaternary History of the Baltic. Acta Universitatis Upsaliensis. Symposia Universitatis Upsaliensis, Annum Quingentesimum Celebrantis 1, 115-125.

Donner, J.J. 1966. A comparison between the Late-glacial and Post-glacial shore-lines in Estonia and south-western Finland. Commentationes Physico-Mathematicae 31, 1-14. 
Donner, J.J. 1969. Land/sea level changes in southern Finland during the formation of the Salpausselkä endmoraines. Bulletin of the Geological Society of Finland 41, $135-150$.

Donner, J. 1978. The dating of the levels of the Baltic Ice Lake and the Salpausselkä moraines in south Finland. Commentationes Physico-Mathematicae 48, 11-38.

Donner, J. 1982. Fluctuations in water level of the Baltic Ice Lake. Annales Academiae Scientiarum Fennicae, Ser. A III, 134, 13-28.

Donner, J. 1992. Is there evidence in the zone of the first Salpausselkä moraine in Finland of a transgression of the Baltic Ice Lake before its drainage? Sveriges Geologiska Undersökning, Ser. Ca, 81, 87-90.

Donner, J., Alhonen, P., Eronen, M., Jungner, H. \& Vuorela, I. 1978. Biostratigraphy and radiocarbon dating of the Holocene lake sediments of Työtjärvi and the peats in the adjoining bog Varrassuo west of Lahti in southern Finland. Annales Botanici Fennici 15, 258-280.

Donner, J. \& Eronen, M. 1981. Stages of the Baltic Sea and Late Quaternary shoreline displacement in Finland. Excursion Guide. INQUA Subcommission on shorelines of northwestern Europe. Excursion in southern Finland with Symposium at Lammi Biological Station 9.-14. September 1981. University of Helsinki, Department of Geology. Stencil 5, 1-53.

Donner, J. \& Raukas, A. 1992. Baltic Ice Lake. In: Raukas, A. \& Hyvärinen, H. (eds.) Geology of the Gulf of Finland. Tallinn: Estonian Academy of Sciences, 112136. (in Russian, with English summary).

Douglas, M.S.V. \& Smol, J.P. 1999. Freshwater diatoms as indicators of environmental change in the High Arctic. In: Stoermer, E.F. \& Smol, J.P. (eds.) The Diatoms: Applications for the Environmental and Earth Sciences. Cambridge: University Press, 227-244.

Eronen, M. 1976. A radiocarbon-dated Ancylus transgression site in south-eastern Finland. Boreas 5, 65-76.

Eronen, M. 1983. Late Weichselian and Holocene shore displacement in Finland. In: Smith, D.E. \& Dawson, A.L. (eds.) Shorelines and Isostasy. Institute of British Geographers, Special Publication 16. London: Academic Press, 183-207.

Eronen, M. \& Haila, H. 1982. Shoreline displacement near Helsinki, southern Finland, during the Ancylus Lake stage. Annales Academiae Scientiarum Fennicae, Ser. A III, 134, 111-129.

Fyfe, G.J. 1990. The effect of water depth on ice-proximal glaciolacustrine sedimentation: Salpausselkä I, southern Finland. Boreas 19, 147-164.

Glückert, G. 1977. Itämeren korkeimman rannan kehityksestä Salpausselkä-vyöhykkeessä Lohjan-KarkkilanLopen alueella. Publications of the Department of Quaternary Geology, University of Turku 65, 1-22.

Glückert, G. 1995. The Baltic Ice Lake in South Finland and its outlets. Quaternary International 27, 47-51.

Glückert, G. \& Ristaniemi, O. 1982. The Ancylus transgression west of Helsinki, South Finland - A preliminary report. Annales Academiae Scientiarum Fennicae,
Ser. A III, 134, 99-110.

Grimm, E.C. 1992. TILIA and TILIA GRAPH: Pollen spreadsheet and graphics program. 8th International Palynological Congress. Program and Abstracts. Aix-enProvence, France, 56.

Haworth, E.Y. 1976. Two Late-Glacial (Late Devensian) diatom assemblage profiles from northern Scotland. New Phytologist 77, 227-256.

Heinsalu, A. 1997. Results of diatom investigation of three sediment sequences from Suursaari (Hogland), Gulf of Finland. Geological Survey of Finland, Report P 34.4.009, 1-44.

Hofmann, E. 1841. Geognostische Beobachtungen auf eines reise von Dorpat bis Abo. Beiträge zur Kenntnis des Russischen Reiches IV, 97-142.

Hustedt, F. 1930. Bacillariophyta (Diatomeae). Die Süsswasser-flora Mitteleuropas, Heft 10. Jena: Verlag von Gustav Fischer. 466 p.

Hustedt, F. 1927-1966. Die Kieselalgen Deutschlands, Österreichs und der Schweiz unter Berücksichtigung der übrigen Länder Europas sowie der angrenzenden Meeresgebiete. Teil 1-3. Dr. L. Rabenhorst's Kryptogamen-Flora von Deutschland, Österreich und der Schweiz, Band 7. Reprint 1991, Koeltz Scientific Books, USA. 7/1 (1927-1930) 920 p., 7/2 (1931-1959) 845 p., 7/3 (1961-1966) $816 \mathrm{p}$.

Hyvärinen, H. 1971. Two Late Weichselian stratigraphical sites from the eastern foreland of the Salpausselkä in Finland. Societas Scientiarum Fennica, Commentationes Biologicae 40, 1-12.

Hyvärinen, H. 1973. The deglaciation history of eastern Fennoscandia - recent data from Finland. Boreas 2, 85102.

Jones, V.J. 1993. The use of diatoms in lake sediments to investigate environmental history in the Maritime Antarctic: an example from Sombre Lake, Signy Island. Antarctic Special Topic, 91-95.

Karukäpp, R., Raukas, A. \& Hyvärinen, H. 1992. Deglaciation of the area. In: Raukas, A. \& Hyvärinen, H. (eds.) Geology of the Gulf of Finland. Tallinn: Estonian Academy of Sciences, 112-136. (in Russian, with English summary).

Kessel, H. \& Raukas, A. 1979. The Quaternary History of the Baltic. Estonia. In: Gudelis, V. \& Königsson, L.-K. (eds.) The Quaternary History of the Baltic. Acta Universitatis Upsaliensis, Symposia Universitatis Upsaliensis, Annum Quingentesimum Celebrantis 1, 127-146.

Kessel, H., Raukas, A., Hyvärinen, H. \& Donner, J. 1988. The Echeneis stage in the Baltic Sea history. Annales Academiae Scientiarum Fennicae, Ser. A III, 148, 13-23.

Kingston, J.C. 1984. Palaeolimnology of a lake and adjacent fen in southeastern Labrador: Evidence from diatom assemblages. In: Mann, D.G. (ed.) Proceedings of the 7th International Diatom Symposium. Koeningstein: Otto Koeltz, 443-453.

Korhola, A.A. \& Tikkanen, M.J. 1991. Holocene development and early extreme acidification in a small hilltop lake in southern Finland. Boreas 20, 333-356. 
Korsman, T. \& Birks, H.J.B. 1996. Diatom-based water chemistry reconstructions from northern Sweden: A comparison of reconstruction techniques. Journal of Paleolimnology 15, 65-77.

Krammer, K. \& Lange-Bertalot, H. 1986-1991. Bacillariophyceae. Teil 1-4. Süßwasserflora von Mitteleuropa, Band 2. Stuttgart, New York: Gustav Fischer Verlag. 2/1 (1986) 876 p., 2/2 (1988) 596 p., 2/3 (1991) 576 p, 2/4 (1991) $437 \mathrm{p}$.

Kullman, L. 1996. Norway spruce present in the Scandes Mountains, Sweden at 8000 BP: new light on Holocene tree spread. Global Ecology and Biogeography Letters 5, 94-101.

Kurki, M. 1915. Suursaaren maantieteestä. Suomen Maantieteellisen yhdistyksen julkaisuja 10, 1-60.

Lagorio, A. 1876. Microscopische Analyse ostbaltischen Gebirgsarten. Archiv für die Naturkunde Liv-, Est- und Kurlands Ser I, Bd VIII, 49-74.

Lange-Bertalot, H. \& Moser, G. 1994. Brachysira, Monographie der Gattung. Bibliotheca Diatomologica 29, 1212.

Lemberg, J. 1868. Die Gebirgsarten der Insel Hochland, chemisch-geognostisch untersucht. Archiv für die Naturkunde Liv-, Est- und Kurlands Ser II, Bd IV, 337392.

Lotter, A.F., Pienitz, R. \& Schmidt, R. 1999. Diatoms as indicators of environmental change near arctic and alpine treeline. In: Stoermer, E.F. \& Smol, J.P. (eds.) The Diatoms: Applications for the Environmental and Earth Sciences. Cambridge: University Press, 205-226.

Männil, R. \& Pirrus, R. 1963. Late glacial deposits in the profiles of Haljala and Võru. Eesti NSV Teaduste Akadeemia Geoloogia Instituudi Uurimused 12, 95-105. (in Russian, with English summary).

Mölder, K. \& Tynni, R. 1967-1973. Über Finnlands rezente und subfossile Diatomeen 1-VII. Bulletin of the Geological Society of Finland, I (1967) 39, 199-217; II (1986) 40, 151-170; III (1969) 41, 235-251; IV (1970) 42; 129-144; V (1971) 43, 203-220; VI (1972) 44, 141149; VII (1973) 45, 159-179.

Pirrus, R. 1969. Stratigraphic division of South Estonian late glacial deposits by means of pollen analysis. ENSV TA Toimetised, Geoloogia 18 (2), 181-190. (in Russian, with English summary).

Puura, V., Amantov, A., Koistinen, T. \& Laitakari, I. 1992. Prequaternary geology of the Gulf of Finland and the neighbouring areas: Precambrian basement. In: Raukas, A. \& Hyvärinen, H. (eds.) Geology of the Gulf of Finland. Tallinn: Estonian Academy of Sciences, 13-30. (in Russian, with English summary).

Ramsay, W. 1892. Kertomus karttalehtiin N 19 ja 20. Suursaari ja Tytärsaari. 1-27.

Raukas, A. 1986. Deglaciation of the Gulf of Finland and adjoining areas. Bulletin of the Geological Society of Finland 58, 21-33.

Raukas, A. \& Hyvärinen, H. (eds.) 1992. Geology of the Gulf of Finland. Tallinn: Estonian Academy of Sciences. 422 p. (in Russian, with English summary).
Renberg, I. \& Hellberg, T. 1982. The pH history of lakes in southwestern Sweden, as calculated from the subfossil diatom flora of the sediments. Ambio 11 (1), 30-33.

Repo, R. \& Tynni, R. 1967. Zur spät- und postglazialen Entwicklung im Ostteil des Ersten Salpausselkä. Bulletin de la Commission Géologique de Finlande 229, 133159.

Repo, R. \& Tynni, R. 1969. Morphologisch-stratigraphische Grundzüge des östlichen Salpausselkä-Gebiets. Bulletin of the Geological Society of Finland 41, 203229.

Risberg, J., Sandgren, P. \& Andrén, E. 1996. Early Holocene shore displacement and evidence of irregular isostatic uplift northwest of Lake Vänern, western Sweden. Journal of Paleolimnology 15, 47-63.

Ristaniemi, O. \& Glückert, G. 1987. The Ancylus transgression in the area of Espoo - the first Salpausselkä, southern Finland. Bulletin of the Geological Society of Finland 59, 45-69.

Saari, J. 1992. A review of the seismotectonics of Finland. Nuclear Waste Commission of Finnish Power companies. Report YJT-92-29. 76 p.

Saarnisto, M. \& Grönlund, T. 1996. Shoreline displacement of Lake Ladoga - new data from Kilpolansaari. Hydrobiologia 322, 205-215.

Saarse, L., Veski, S., Heinsalu, A., Rajamäe, R. \& Martma, T. 1995. Litho- and biostratigraphy of Lake Päidre, South Estonia. Proceedings of the Estonian Academy of Sciences, Geology 44 (1), 45-59.

Saarse, L., Heinsalu, A., Poska, A., Veski, S., Rajamäe, R., Hiie, S., Kihno, S. \& Martma, T. 1997. Early Holocene shore displacement of the Baltic Sea east of Tallinn (N Estonia). Baltica 10, 13-24.

Saarse, L., Poska, A., Kaup, E. \& Heinsalu, A. 1998. Holocene environmental events in the Viitna area, North Estonia. Proceedings of the Estonian Academy of Sciences, Geology 47 (1), 31-44.

Saarse, L., Poska, A. \& Veski, S. 1999. Alnus and Picea spread and expansion in Estonia. Proceedings of the Estonian Academy of Sciences, Geology 48 (3), 170-186.

Sauramo, M. 1958. Die Geschichte der Ostsee. Annales Academiae Scientiarum Fennicae, Ser. A III, 51, 1-522.

Snoeijs, P. \& Balashova, N. (eds.) 1998. Intercalibration and distribution of diatom species in the Baltic Sea. The Baltic Marine Biologist Publication No. 16e (vol. 5). Uppsala: Opulus Press. 144 p.

Stabell, B. 1985. The development and succession of taxa within the diatom genus Fragilaria Lyngbye as a response to basin isolation from the sea. Boreas 14, 273286.

Strömberg, B. 1992. The final stage of the Baltic Ice Lake. Sveriges Geologiska Undersökning, Ser. Ca, 81, 347353.

Svensson, N.-O. 1989. Late Weichselian and Early Holocene shore displacement in the central Baltic, based on stratigraphical and morphological records from eastern Småland and Gotland, Sweden. Lundqua Thesis 25. $195 \mathrm{p}$. 
Svensson, N.-O. 1991. Late Weichselian and Early Holocene shore displacement in the central Baltic Sea. Quaternary International 9, 7-26.

Thomson, P.W. 1929. Die regionale Entwicklungsgeschichte der Wälder Estlands. Tartu Ülikooli Geoloogia Instituudi Toimetised 19. $88 \mathrm{p}$.

Thomson, P.W. 1935. Vorläufige Mitteilungen über die spätglaziale Waldesgeschichte Estlands. Geologiska Föreningens i Stockholm Förhandlingar 57 (1), 84-92.

Tolonen, K. 1967. Über die Entwicklung der Moore in finnischen Nordkarelien. Annales Botanici Fennici 4, 219416.

Tynni, R. 1966. Über spät- und postglaziale Uferverschiebung in der Gegend von Askola, Südfinnland. Bulletin de la Commission Géologique de Finlande 223. 97 p.

Tynni, R. 1975-1980. Über Finnlands rezente und subfossile Diatomeen VIII-XI. Geological Survey of Finland, Bulletins. VIII (1975) 274, 1-55; IX (1976) 284, 1-37; X (1978) 296, 1-55; XI (1980) 312, 1-93.
Veski, S. 1998. Vegetation history, human impact and palaeogeography of West Estonia. Pollen analytical studies of lake and bog sediments. Striae 38, 1-119.

Veski, S., Heinsalu, A. \& Vassiljev, J. 1995. Palaeogeographical and vegetational history of the Island of Suursaari (Hogland), Gulf of Finland: Preliminary results. Eesti Loodusuurijate Seltsi Aastaraamat 76, 194-207.

Wasell, A. \& Håkansson, H. 1992. Diatom stratigraphy in a lake on Horseshoe Island, Antarctica: a marine-brackish-fresh water transition with comments on the systematics and ecology of the most common diatoms. Diatom Research 7 (1), 157-194.

Wastegård, S., Andrén, T., Sohlenius, G. \& Sandgren, P. 1995. Different phases of the Yoldia Sea in the northwestern Baltic Proper. Quaternary International 27, 121129.

Wohlfarth, B., Skog, G., Possnert, G. \& Holmquist, B. 1998. Pitfalls in the AMS radiocarbon-dating of terrestrial macrofossils. Journal of Quaternary Science 13 (2), 137-145. 